\title{
Getting Mobile
}

\section{Sally Wilson, Web Services Librarian Graham McCarthy, Lib. Systems Analyst Ryerson University Library}


- Future Trends

(

Future Trends
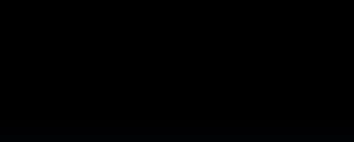

\section{one}




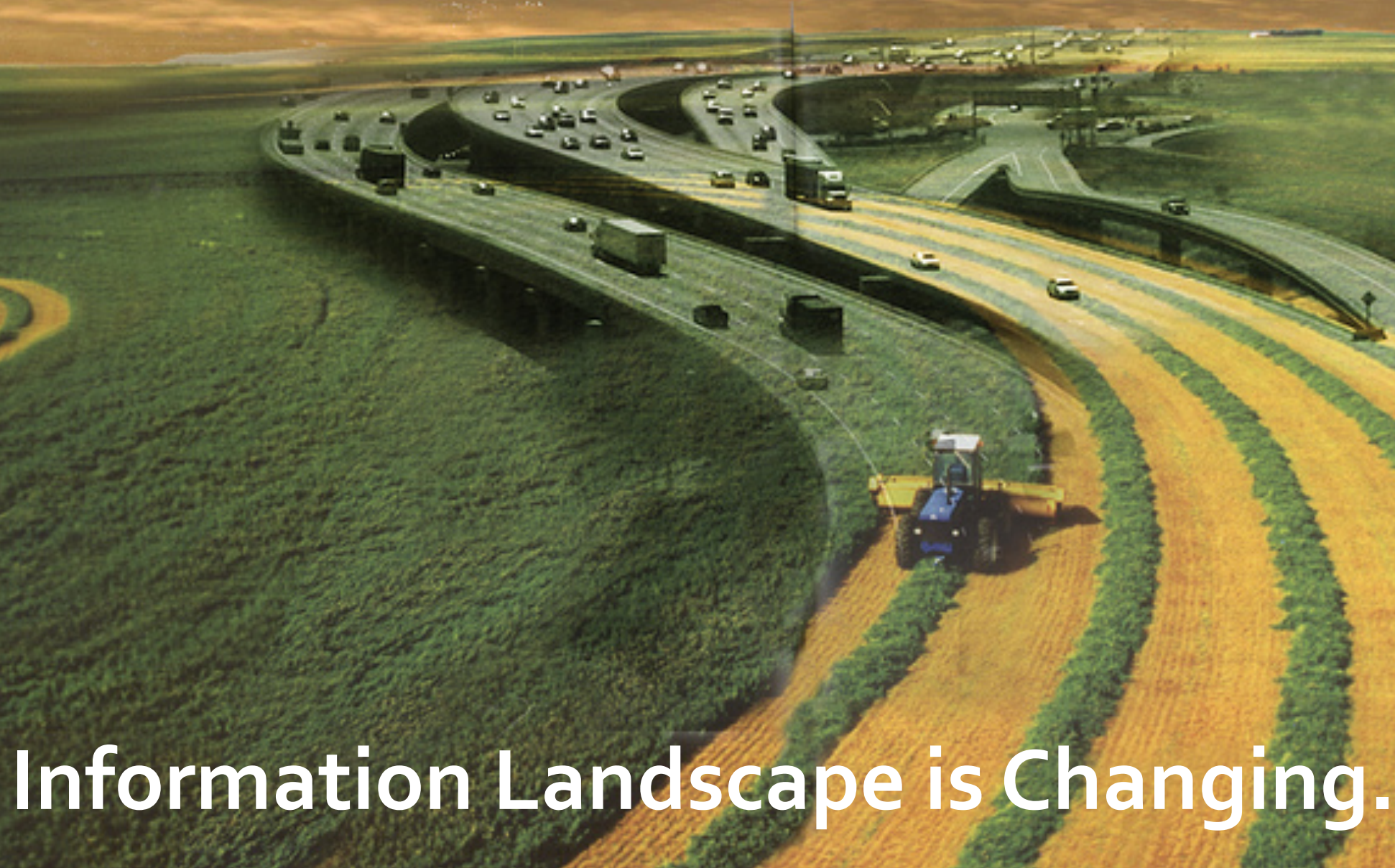

The Information Landscape is Changing. 
Sept $13^{\text {th }} 1956$ - IBM invents first Hard drive. Weighs a ton and costs $\$ 250,000$ USD (approx., in today's dollars) and stores a whopping $5 \mathrm{MB}$ of information

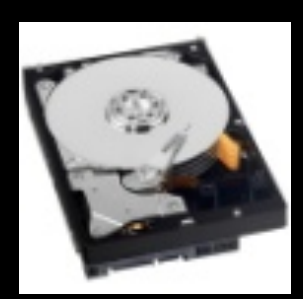

Jan $27^{\text {th }} 2009$ - single hard drive with largest capacity on the market sells for $\$ 400$ (approx.) holds 2TBs (Two Million MBs) of information

Interesting Facts from "How much data is that?":

- Complete works of Shakespeare $=5 \mathrm{MB}$

- Content in an Academic Research Library = 2TBs

- Library of Congress print holdings $=10 \mathrm{TBs}$

- All printed material in the world = 200 Petabytes $(204,800$ TBs) 


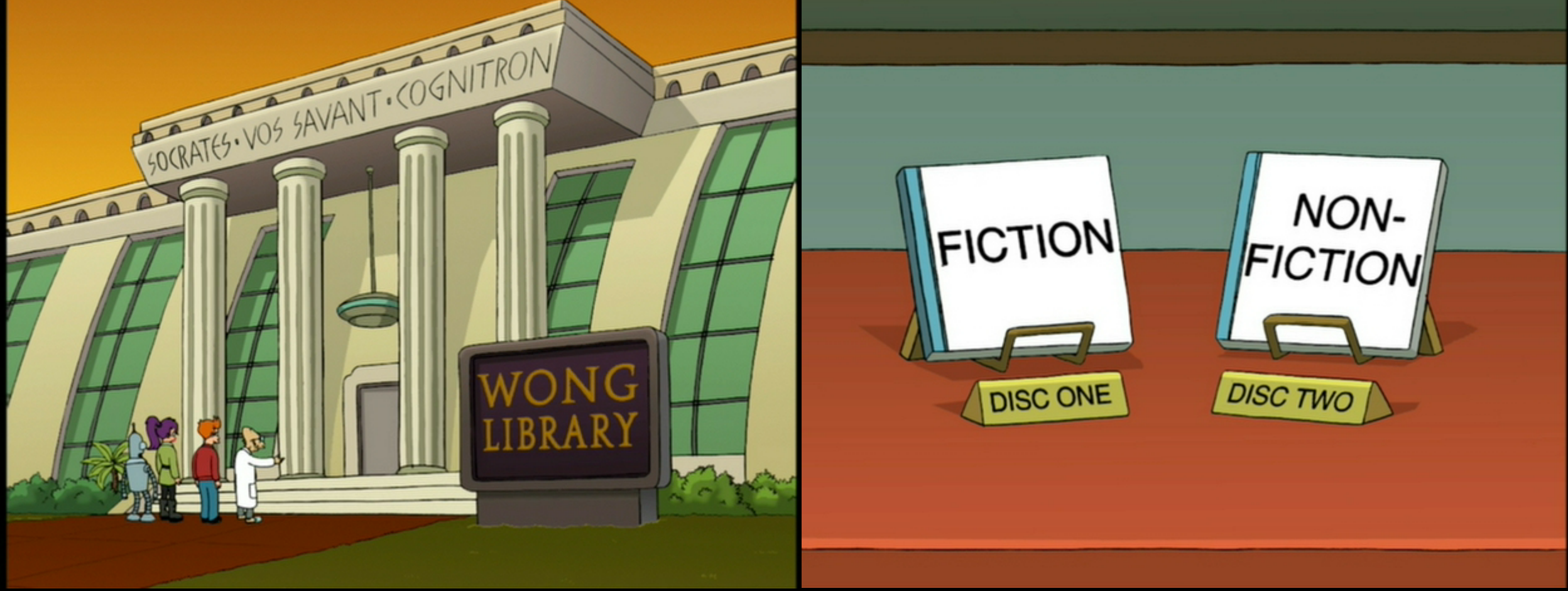

Don't worry, we are not going to get into a debate on digitization...

\section{Concept to remember:}

There has been a major change over the years in the way information has been acquired, stored and consumed. 
- What matters:

- The content

- Relevance to the User

(o)

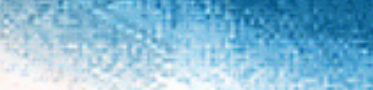

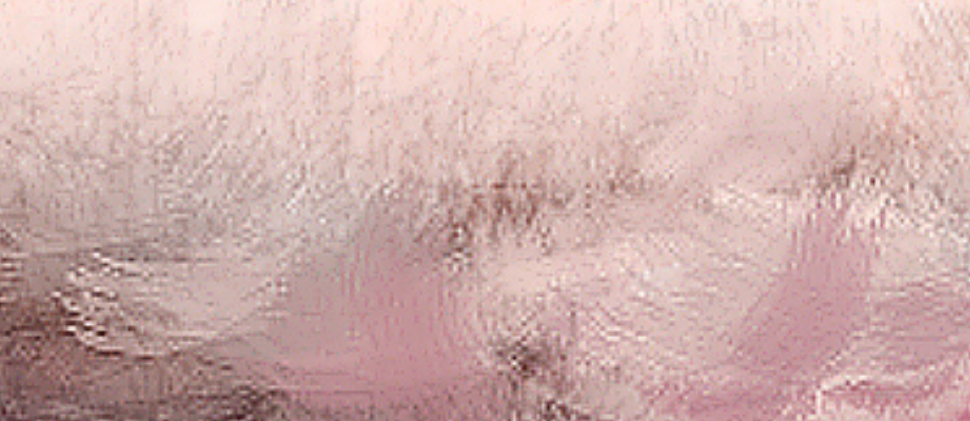


Wires no more.

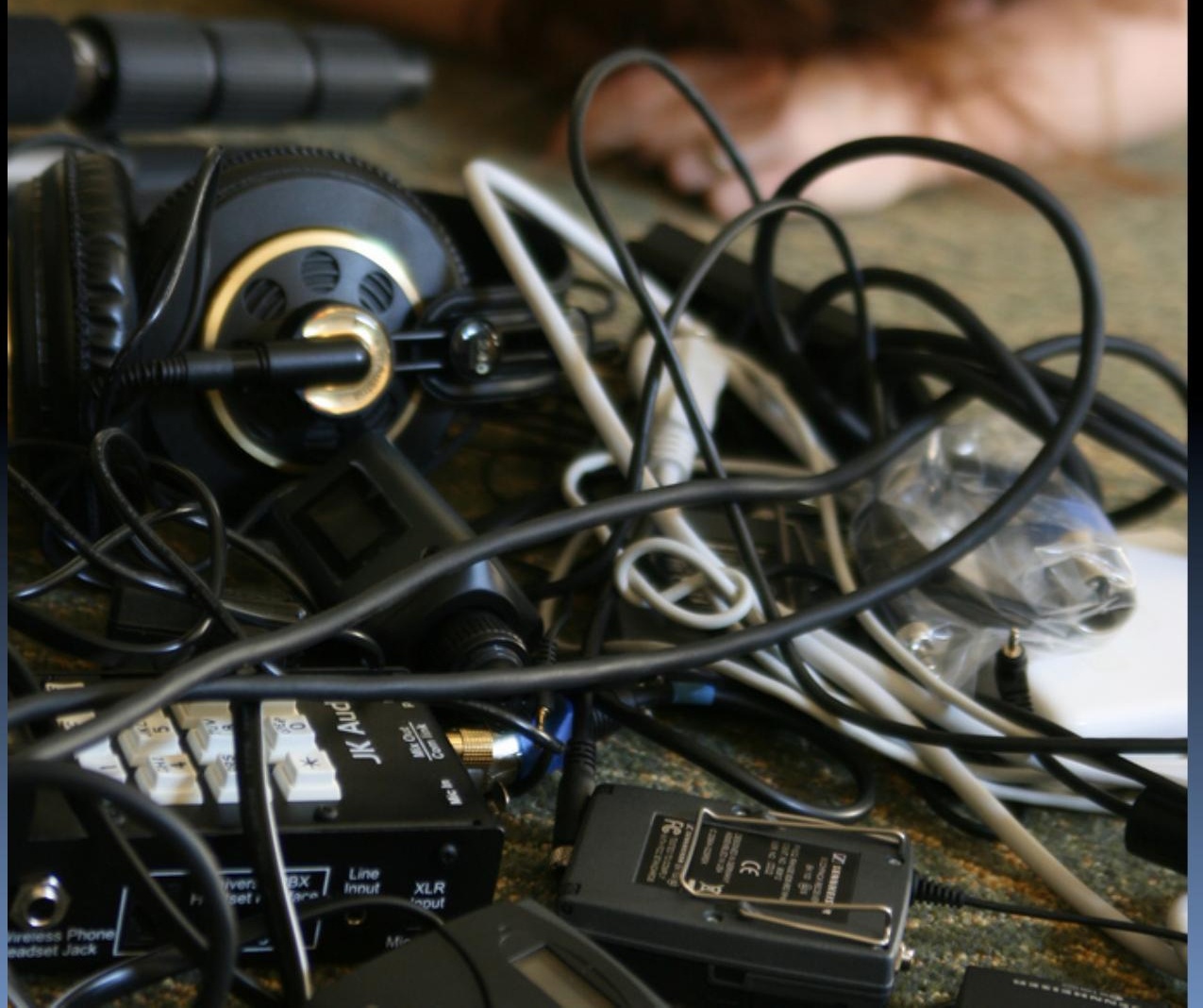




\section{Humans are mobile creatures}

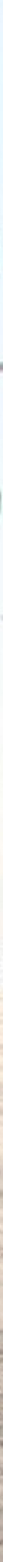



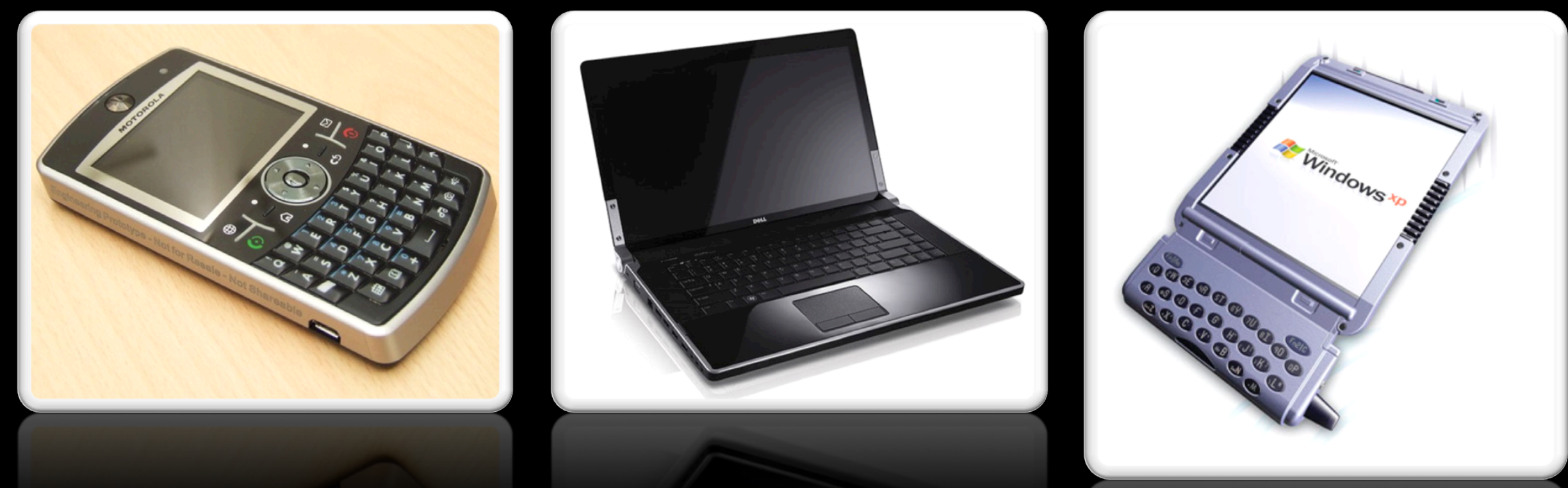

- The way we acquire, store, consume and utilize information has changed rapidly.

- The desired content should seamlessly display on all device types

Emphasis on usability






\section{Before we continue...}

- A brief history of the mobile phone

- Why?

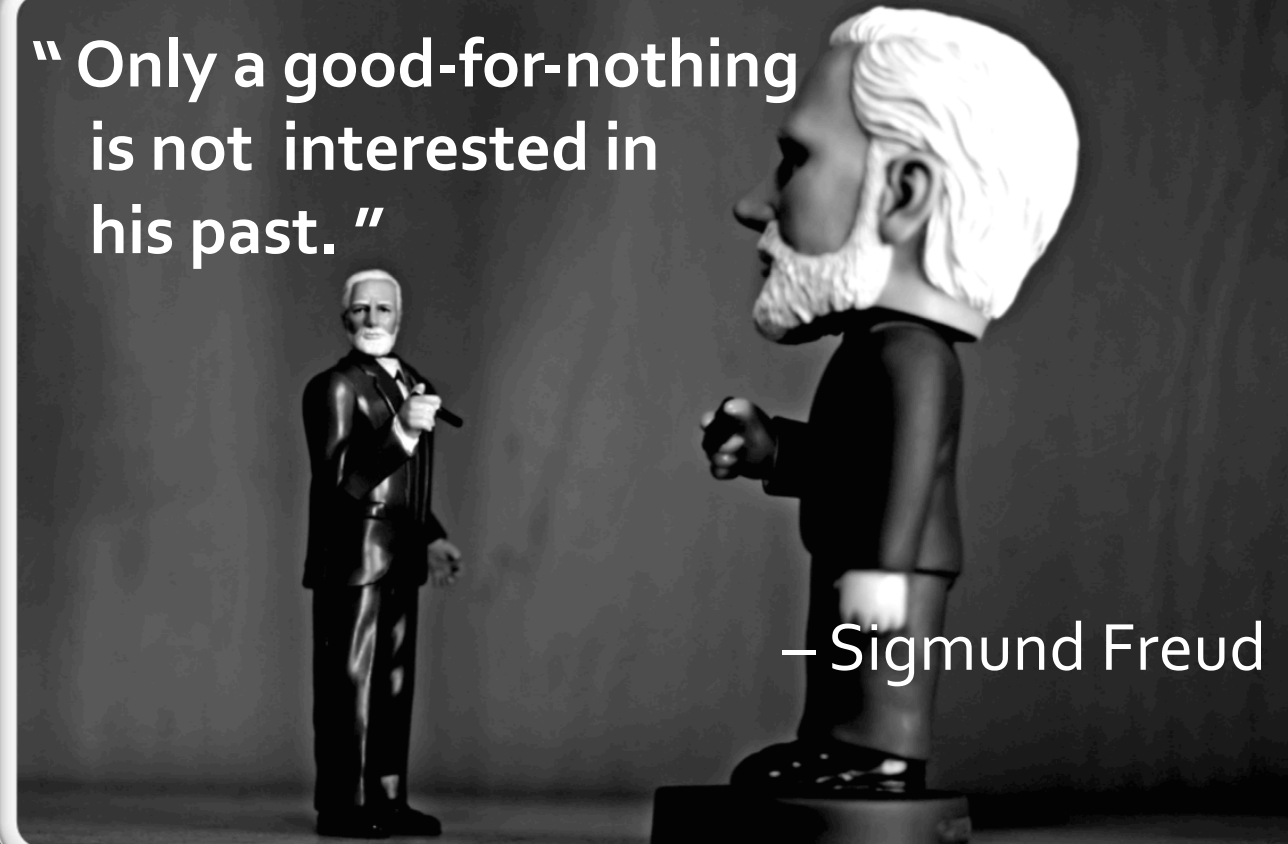

"History is the witness that testifies to the passing of time; it illuminates reality, vitalizes memory, provides guidance in daily life, and brings us tidings of antiquity."

- Cicero 


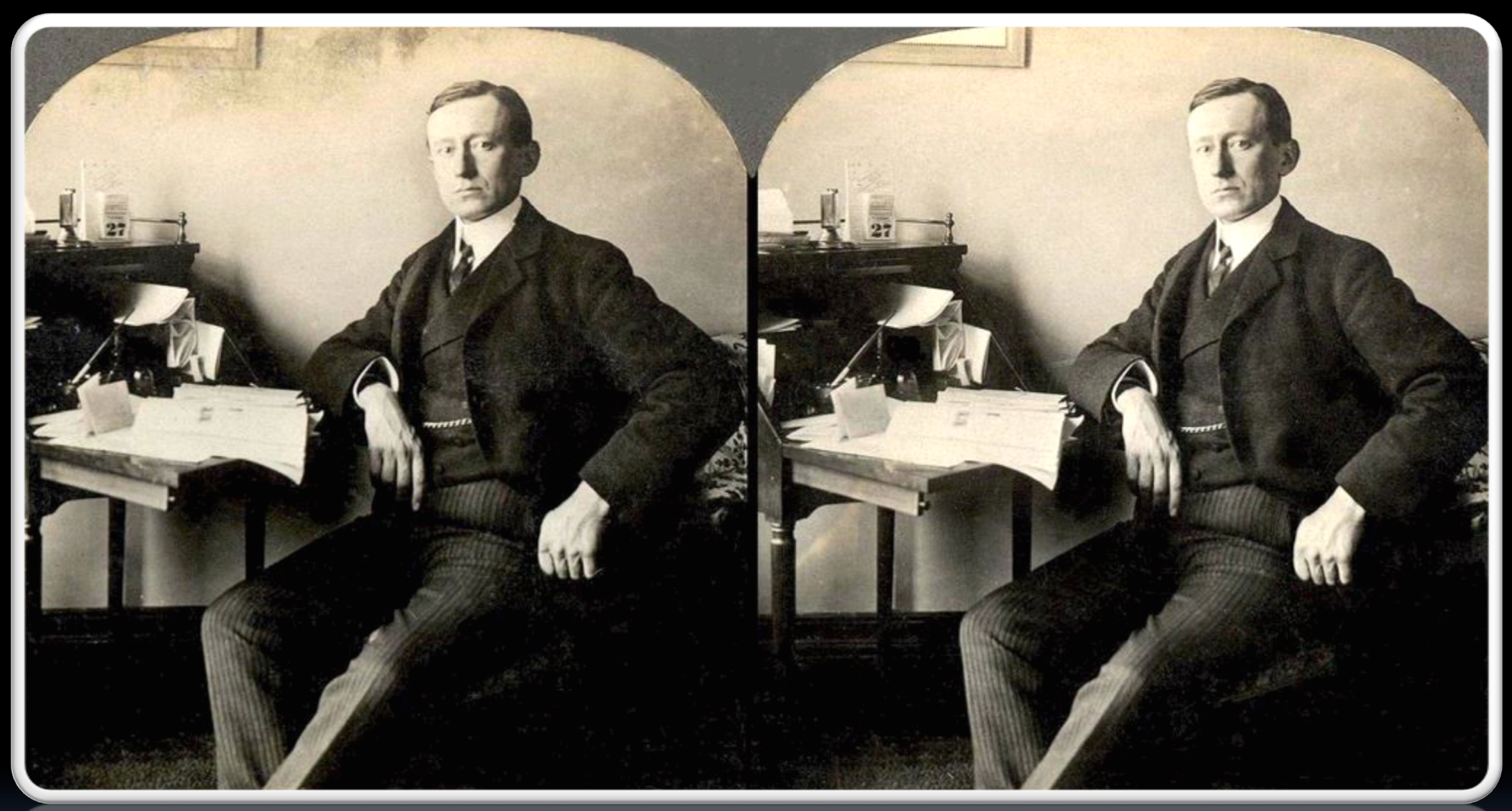

Marconi Wireless Telegraph.

Created in 1896.

First Atlantic transmission in 1901. 


\section{Mobile Telephone System}

Created in 1946.
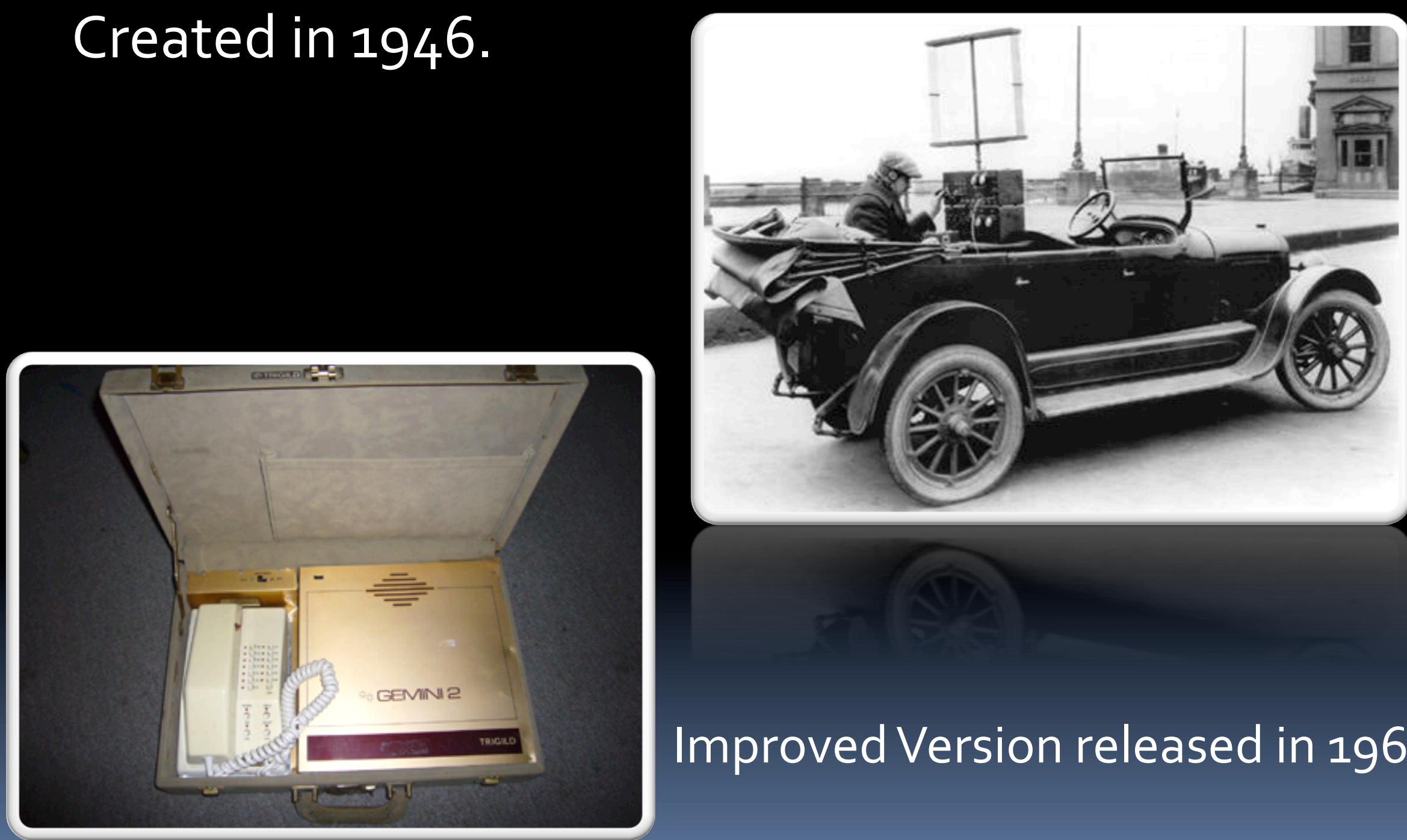

Improved Version released in 1960 
- $1^{\text {st }}$ Gen (80's) replaced the mobile radio phone.

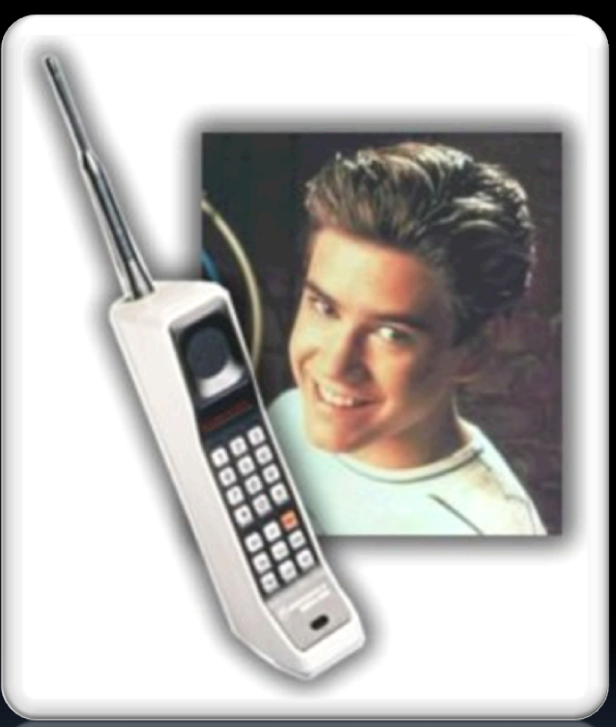

- Analog System

- $2 \mathrm{G}$ (Early 9o's)

- Introduced a Digital System

- Included encrypted for enhanced security

- Introduced data services including SMS text messaging 


\section{$2.5 \mathrm{G}$}

- Extension to the $2 \mathrm{G}$ standards (GPRS/ EDGE/HDCSD)

- Developed for companies who could not make the leap from $2 \mathrm{G}$ to $3 \mathrm{G}$

- Provides additional features (some found in $3 G$ )

- MMS (Multimedia Messaging Service)

- Sending images and video through mobile device

PTT (Push to Talk)

PTP (Point to Point) 
- Early 2000's saw commercial release

- Buzz word used to sell iPhone and BlackBerry Bold smart phones

- Intended for applications other than voice

- Video streaming

- Video calling

- High Speed Internet Access

Downloading Audio/Video/Pictures/ Applications 
- This is where we are in 2009 in terms of our mobile telecommunications technology

- Other Mobile Technologies:

- Laptops/Netbooks

- E-Book Reader / Amazon Kindle 


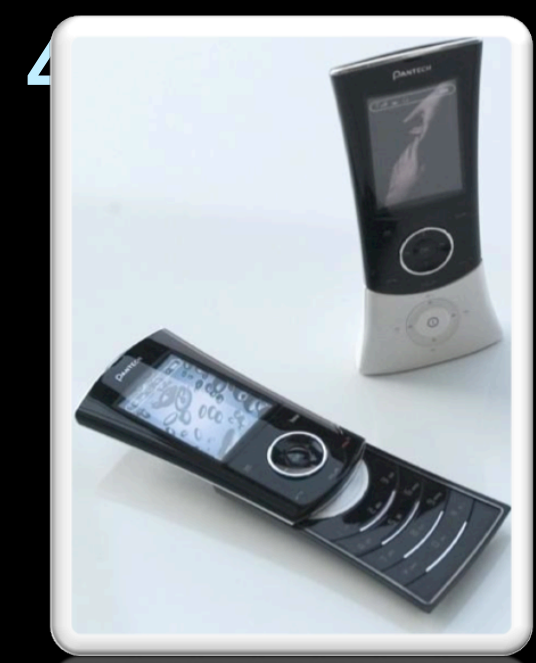

- 2010 release of $4 \mathrm{G}$ standard

- Next evolution in Wireless Communications Technology

- "Anytime, Anywhere" access to voice, data and streaming media services

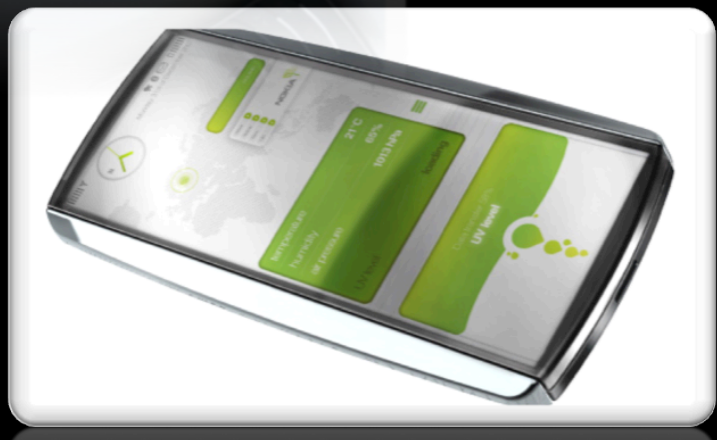

- Services:

- MMS (Multimedia Messaging Service)

- DVB (Digital Video Broadcasting)

$\square$ Video Chat

$\square$ Mobile TV and HDTV

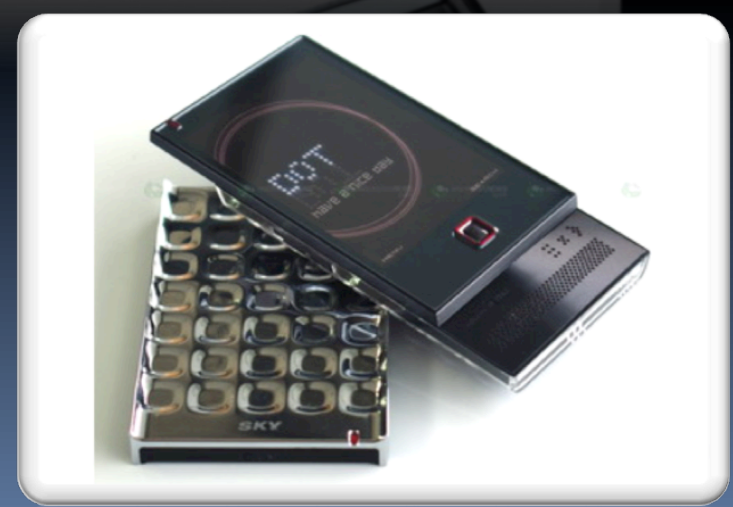

- Aiming to reach broadband speeds:

- $100 \mathrm{mb} / \mathrm{s}$ moving at high speeds (i.e. in a vehicle or on a train or plane) $1 \mathrm{gb} / \mathrm{s}$ in a fixed position 
- Drastic changes in Communications Technologies

- Powerful technologies which can adapt to our mobile lifestyles

How does this fit within academic institutions and especially for libraries? 
E-learning has become a substantial building blo within higher education.

- Many benefits:

24 hour access to resources

On or off campus access (as long as one has interne: access)

- Distance Education 


\section{From "e-" to "m-" Learning}

- $m$-learning extends the e-learning concept by adding the mobile computing element

- Access to resources wherever you are

- Strong searching capabilities

- Rich User Interaction

- Independence from a location in space and time 

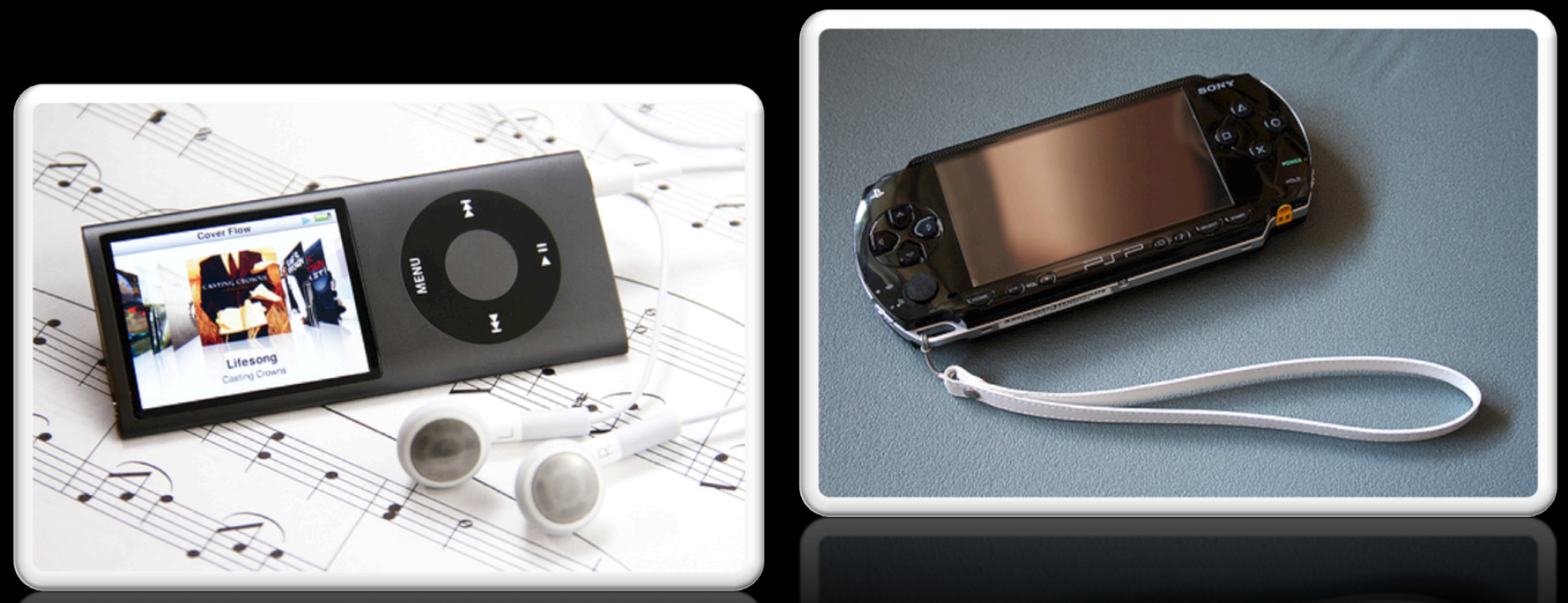

Students entering University have been exposed to an assortment of technological devices
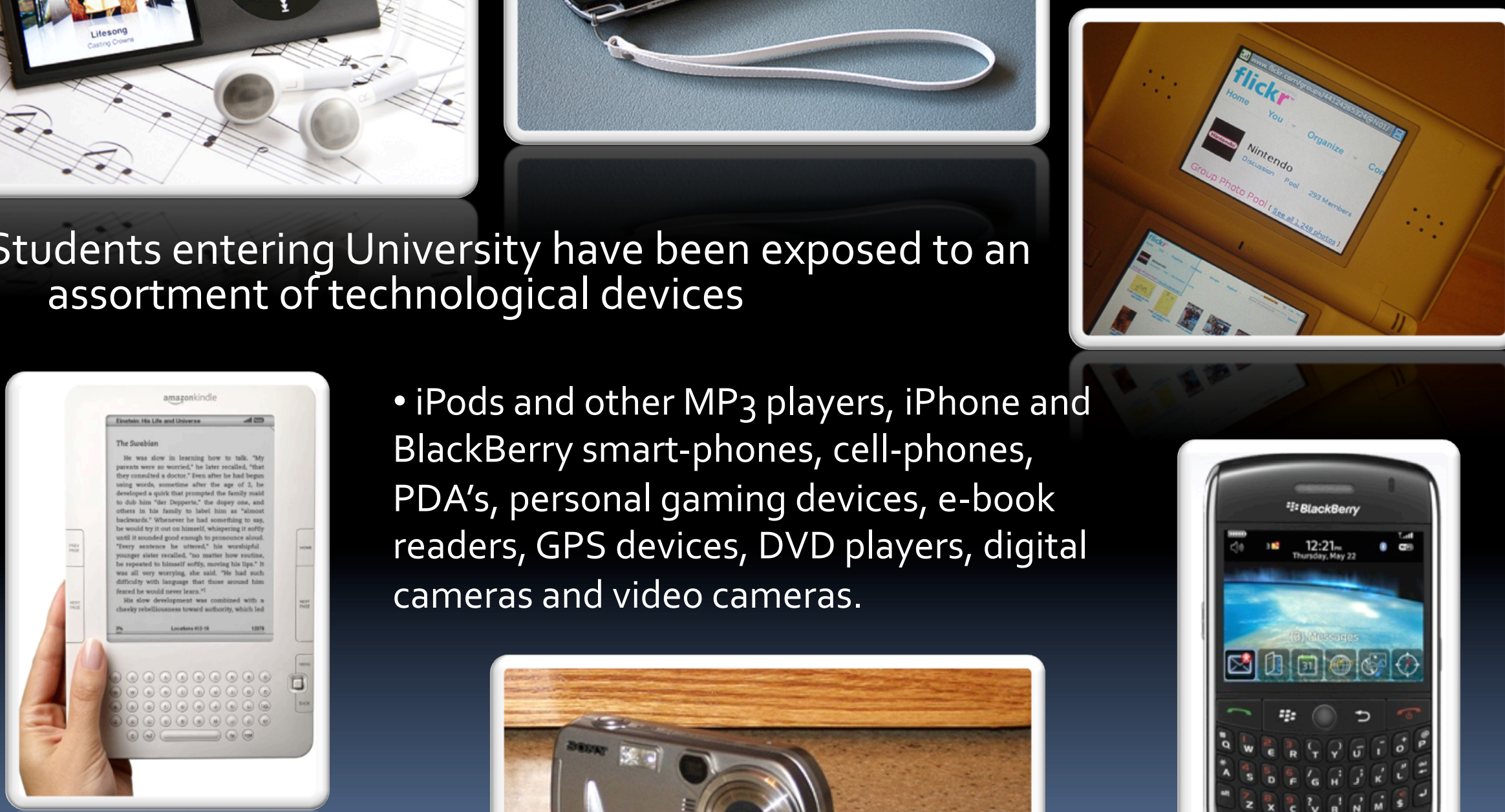

- iPods and other MP3 players, iPhone and BlackBerry smart-phones, cell-phones, PDA's, personal gaming devices, e-book readers, GPS devices, DVD players, digital cameras and video cameras.
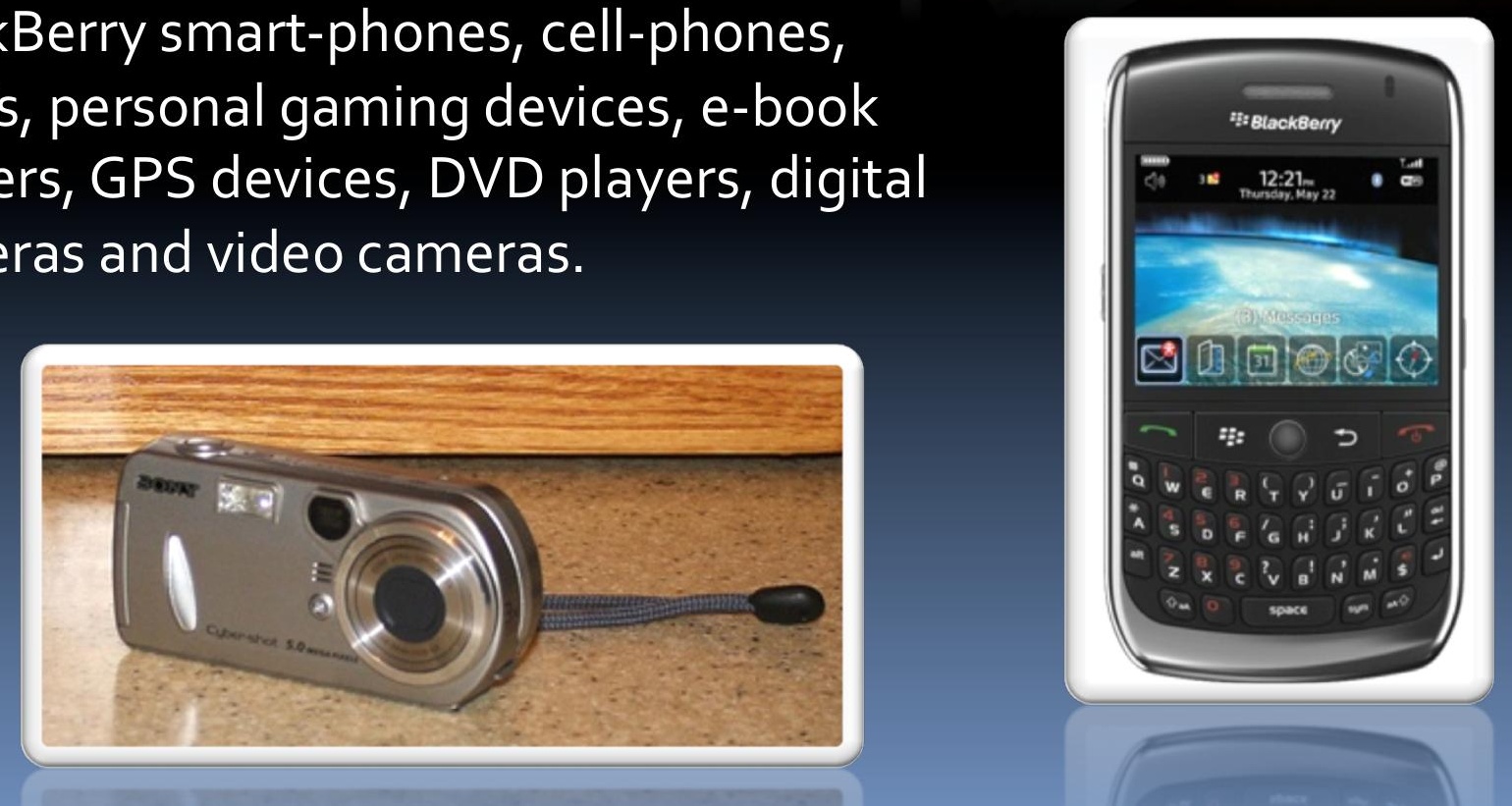
- Technologies cause problems:

- Attention during lectures (i.e., web- surfing, gaming)

- Disruptions (i.e., cell phones)

Please Silence All

Cell Phones and

Communication

Devices

- Technologies assist in learning:

Thank You

$\square$ designing engaging learning experiences

- Alternative teaching methods

Multi-media

Discovery of information from the internet 


\section{Library's Role in this shift}

- Information needs of patrons are changing

- Library must cater to this adapting needs

- No longer answering "Encyclopedia Style" questions.

- Performing deeper levels of service

- Comparing Strengths and Weaknesses of various resources for the patrons

Engaging in reference interviews about complex, often obscure topics not easily searchable on the internet

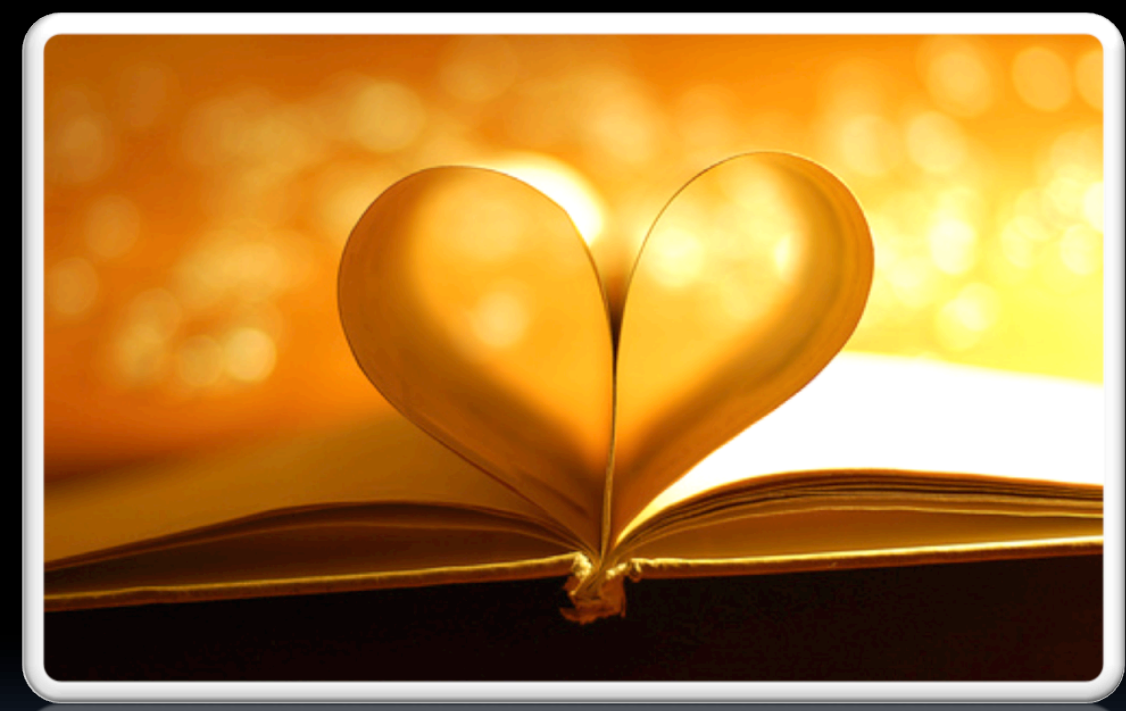


Library's Role in this shift

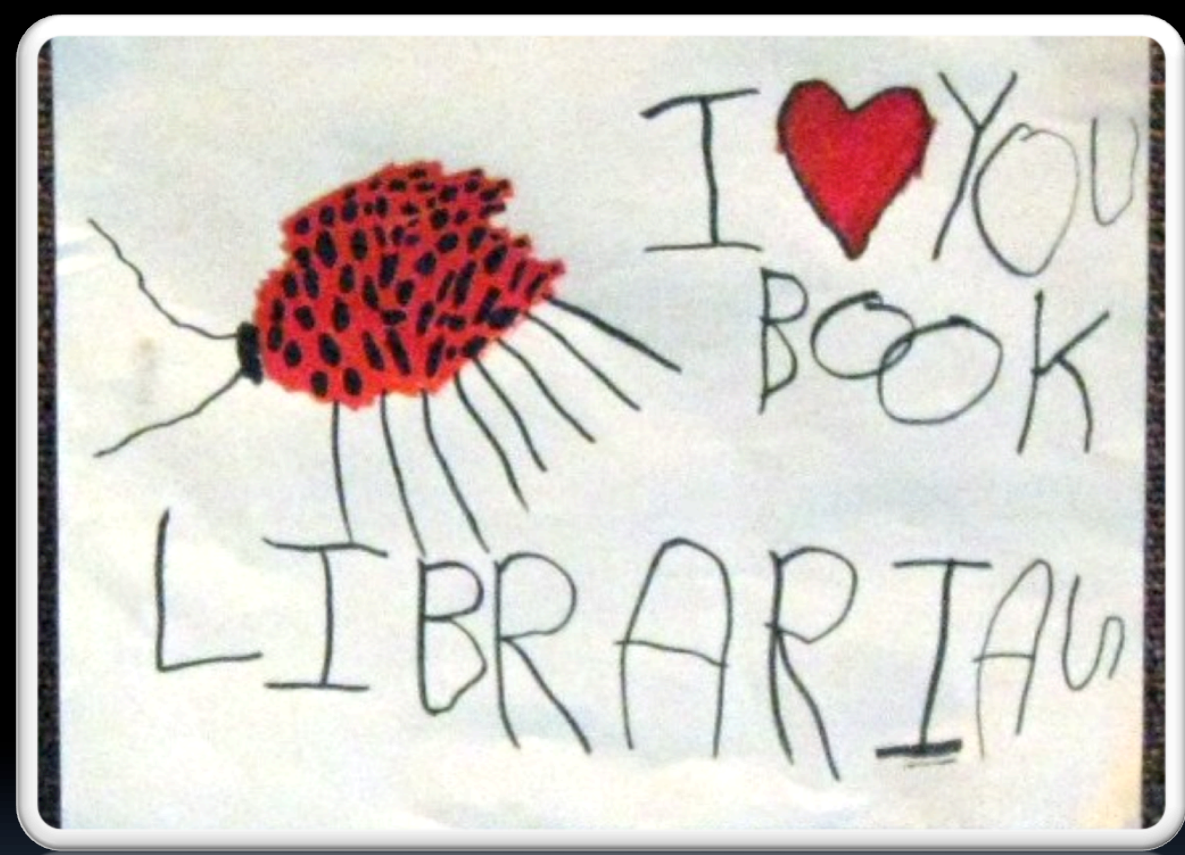

- Facilitate the delivery of these resources to patron devices

- Information needs to be formatted properly for that device and should be contextually relevant to their location in space and time. 


\section{Mobile Delivery of Library \\ Services}

- Sense of mobile environment

- Current mobile library services

- Future directions 


\section{Mobile Survey - Nov. 2008}
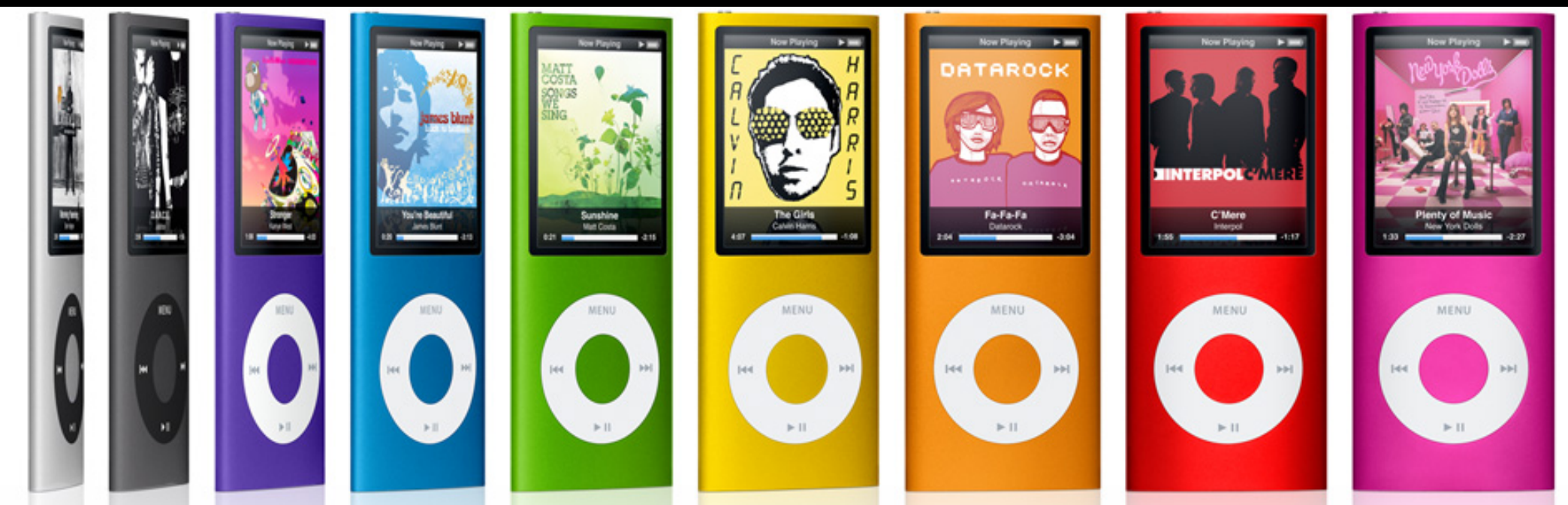

811 responses, primarily undergraduate 


\section{Cell Phone Ownership}

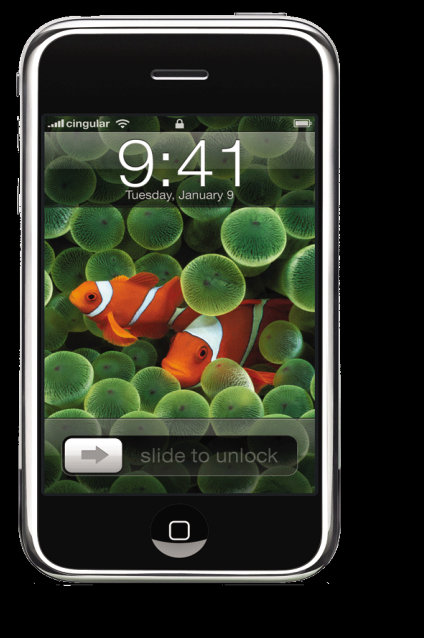

Smart Phone $21 \%$

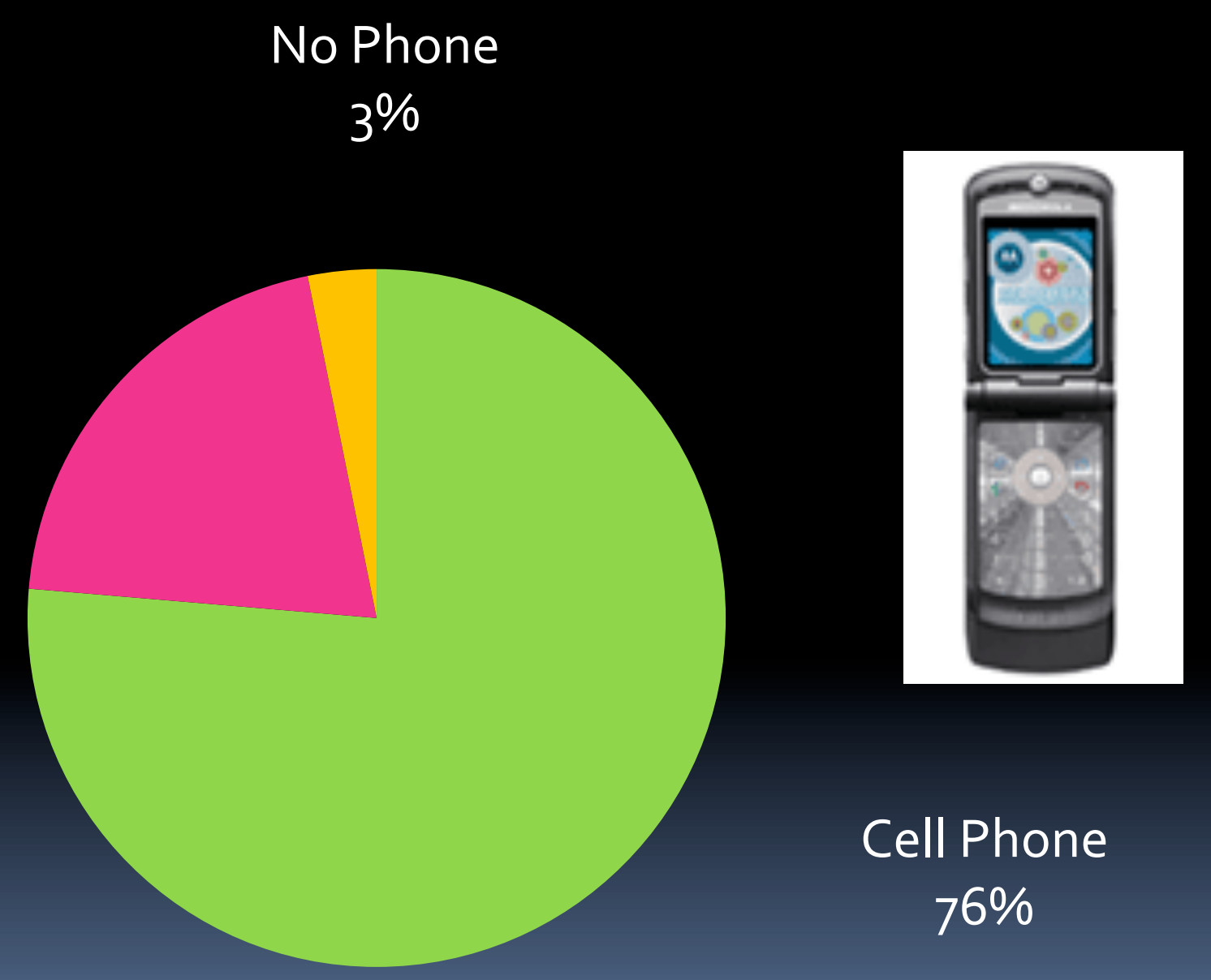




\section{The Mobile Market}

Increase between Jan 2008 and Jan 2009 of Mobile Phone Users Accessing the Internet for:

News and Information

Social Networking
$107 \%$ change $427 \%$ change 


\section{The Mobile Market}

40 million active users of the mobile Internet (15.6\% of cell phone subscribers)

144 million data users (SMS or internet) $-57 \%$ of subscribers

Nielsen Mobile, Worldwide State of the Mobile Web 2008

The mobile device will be the primary connection tool to the internet for most people in the world in 2020

Pew Internet \& American Life, Future of the Internet III, Dec 2008 


\section{Top 4 Uses}
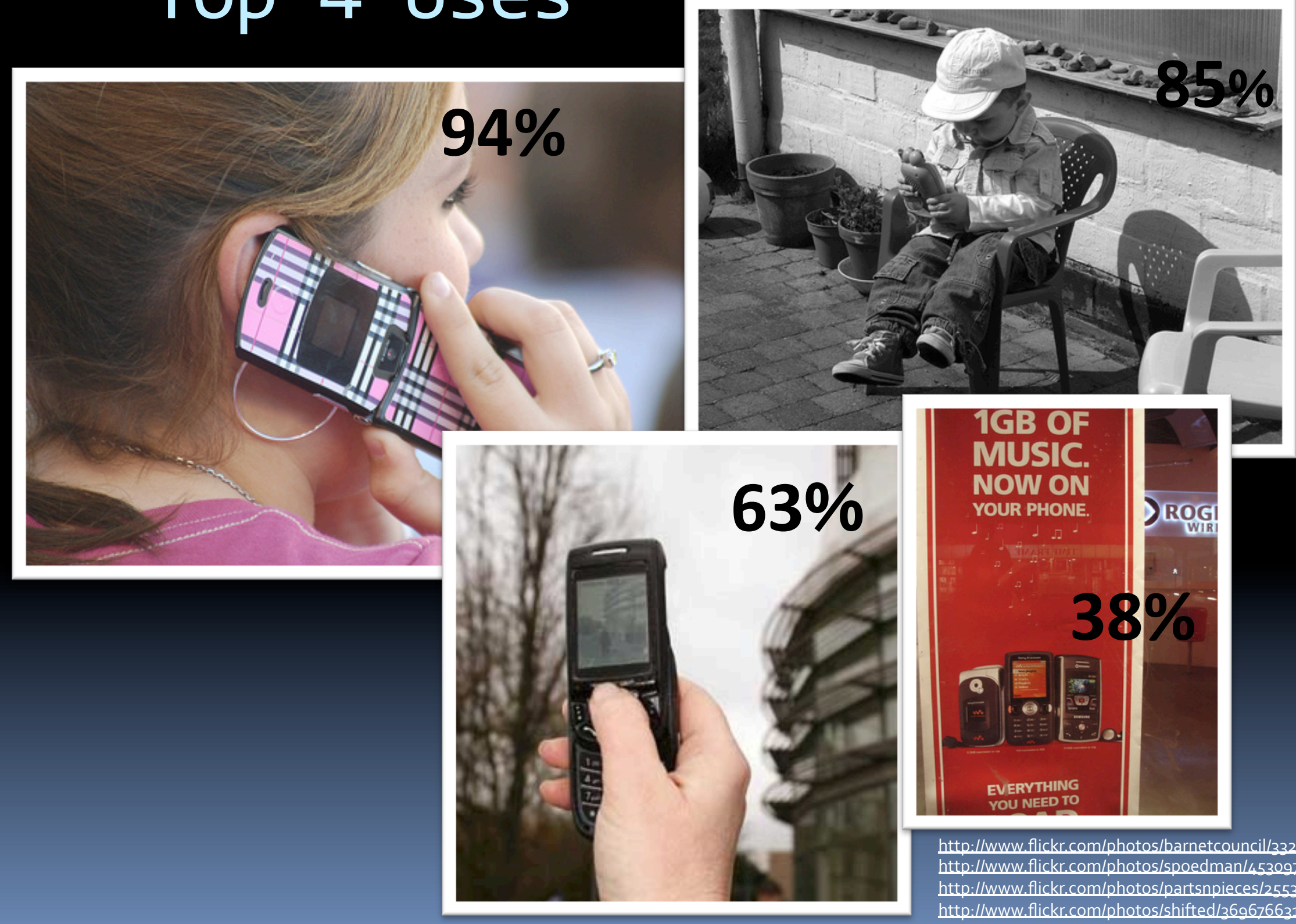

http://www.flickr.com/photos/barnetcouncil//2226252218/sizes/o http://www.flickr.com/photos/spoedman/453097479/sizes/m http://www/flickr.com/photos/partsnpieces/255319183/sizes/m/ http://www_flickr.com/photos/shifted/269676631/sizes/m/ 


\section{Top Internet Uses}

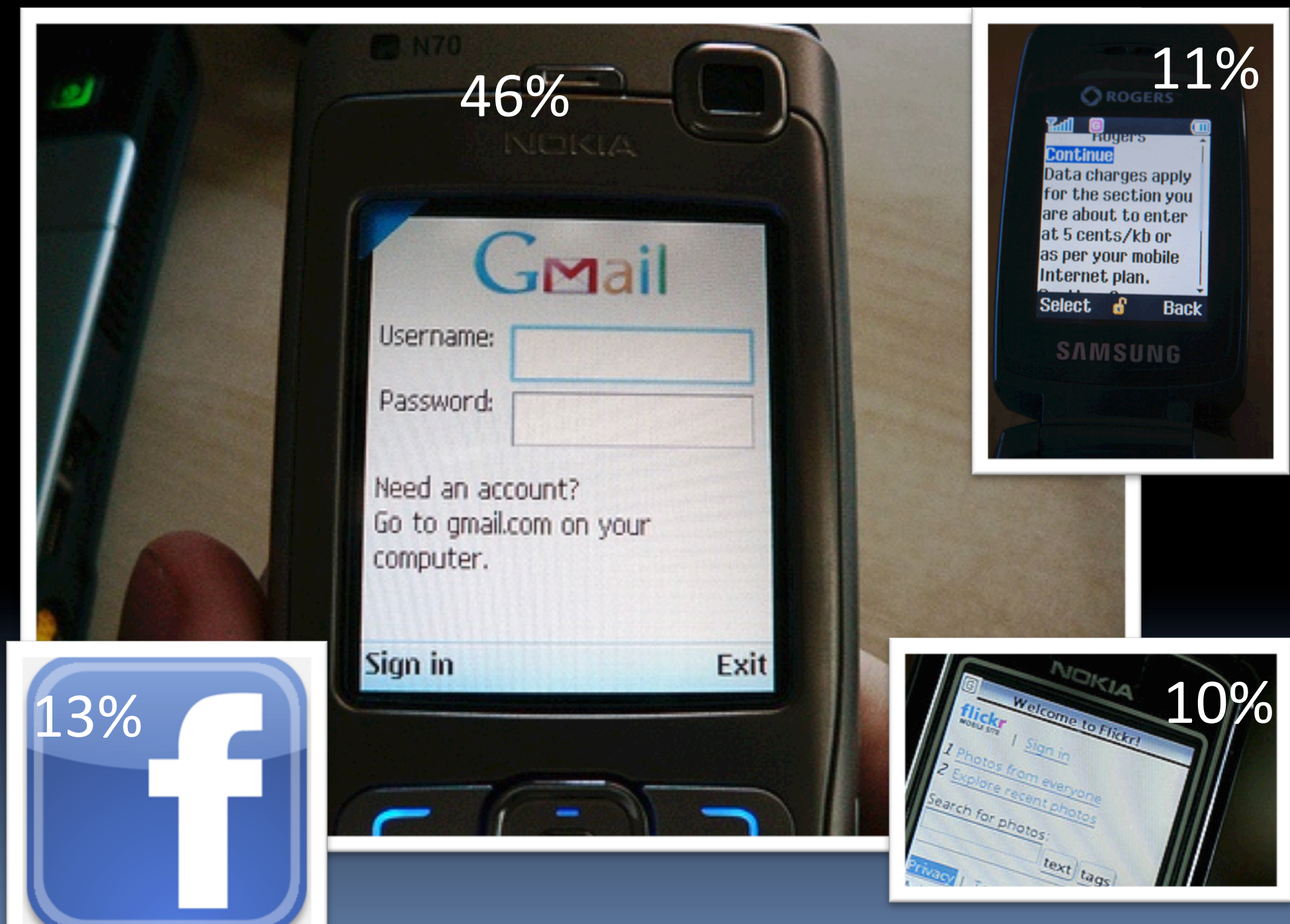




\section{What will your next phone be?}

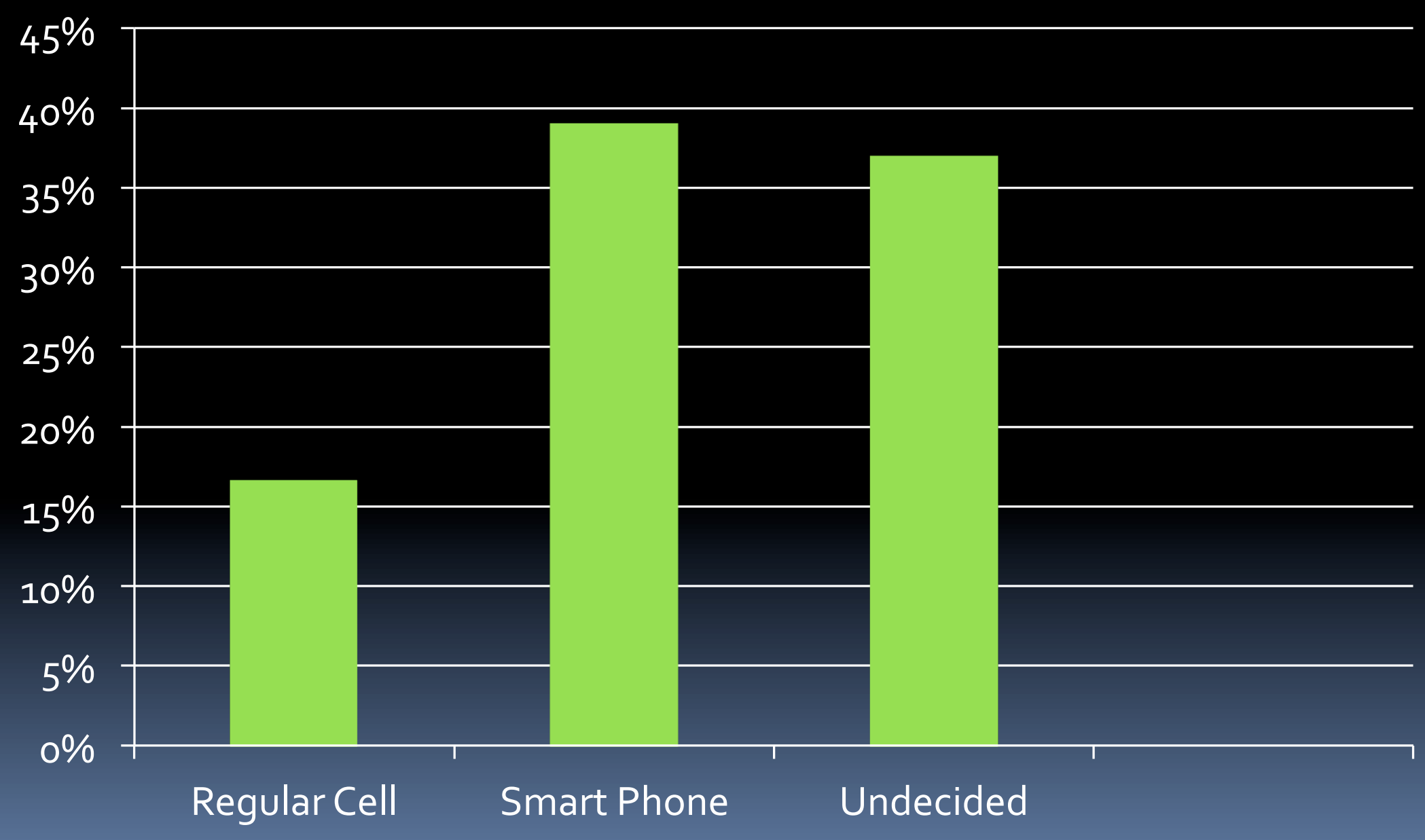




\section{Other wifi enabled devices}

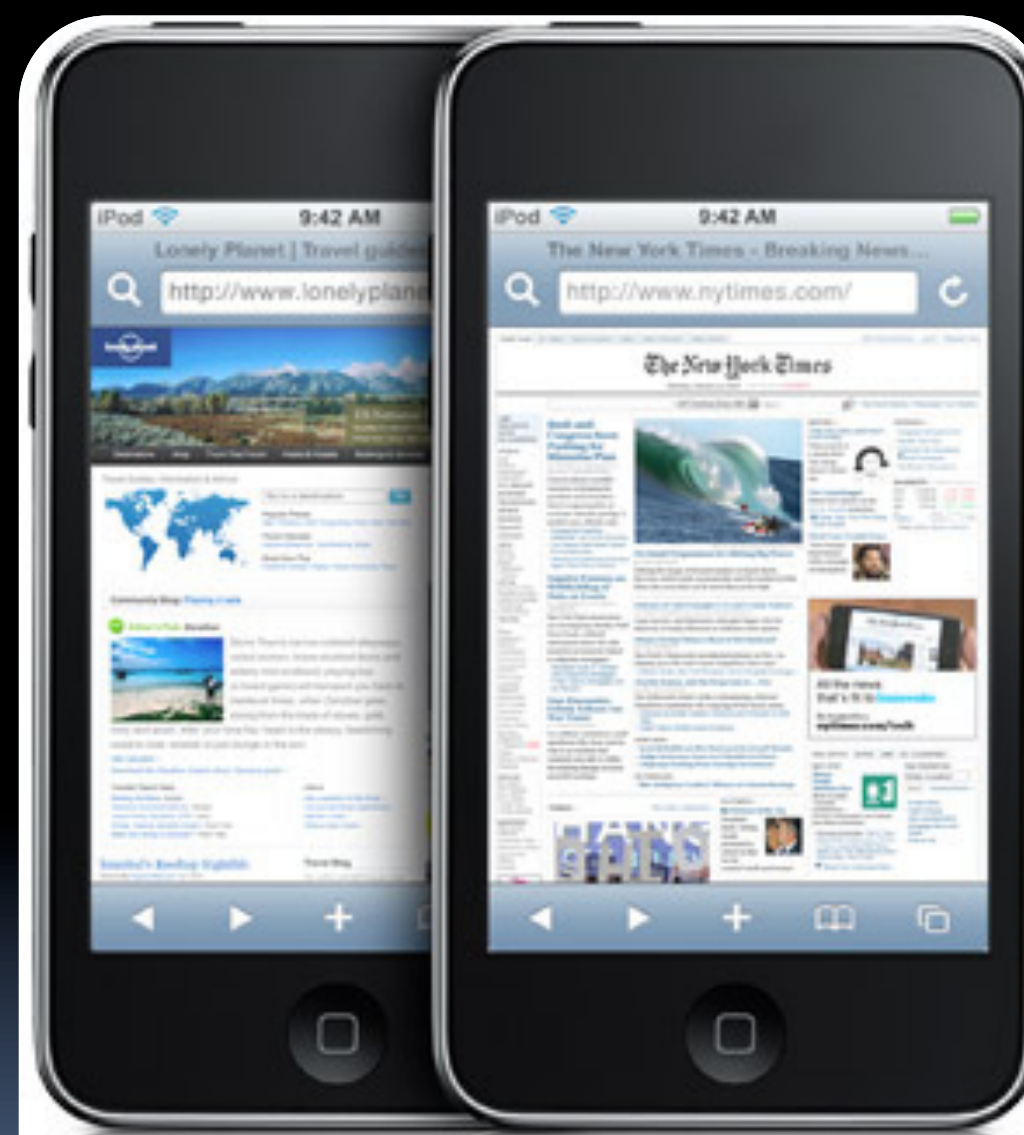

$8.7 \%$ have

$32 \%$ plan to buy 


\section{New features wanted}

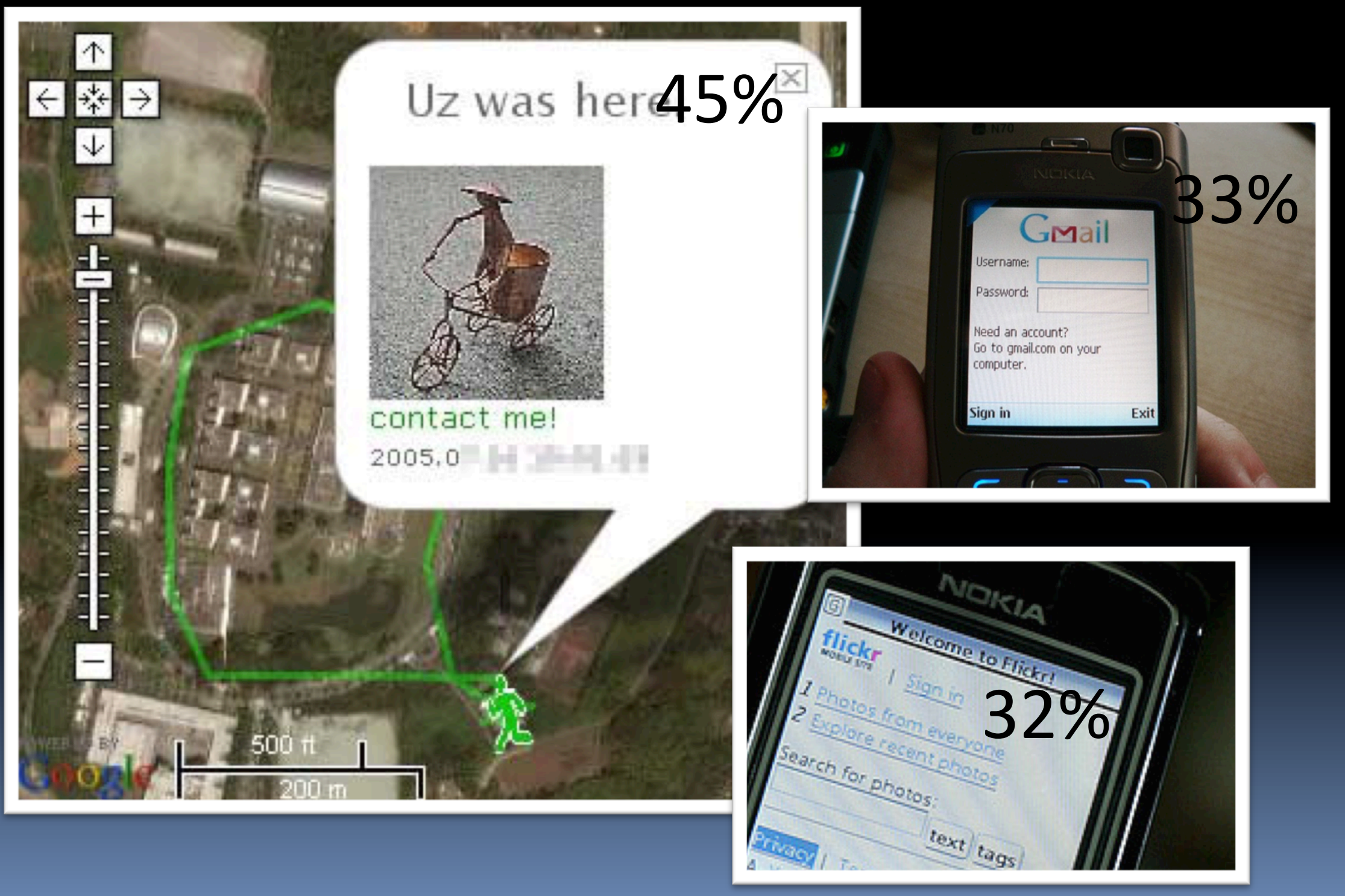




\section{What Library Services do you want on}

your Phone?
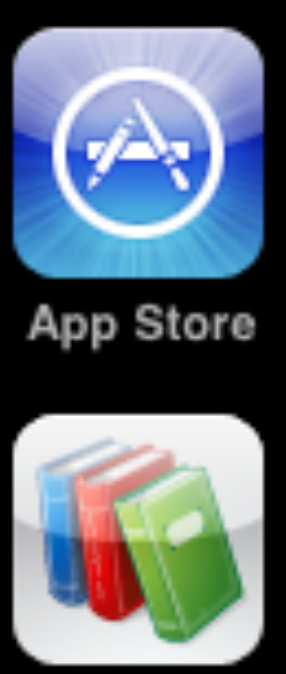

Book Search

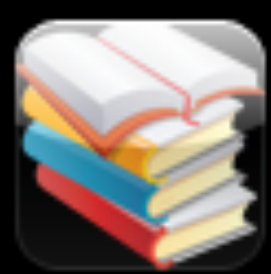

BookShelfLT

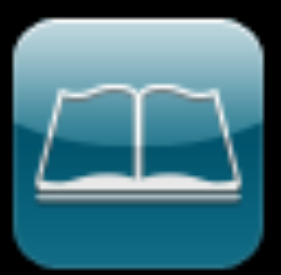

Stanza

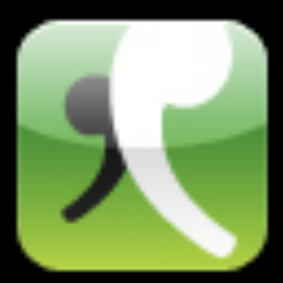

Shortcovers

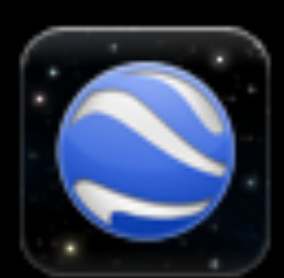

Google Earth

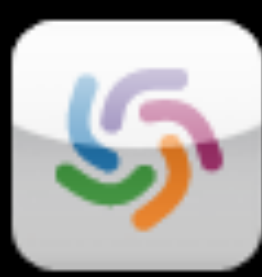

WorldCat

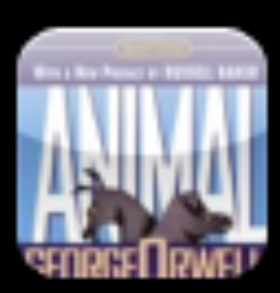

Animal Farm

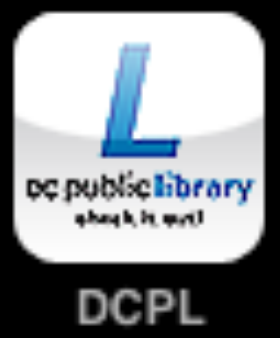




\section{Faster Horse}
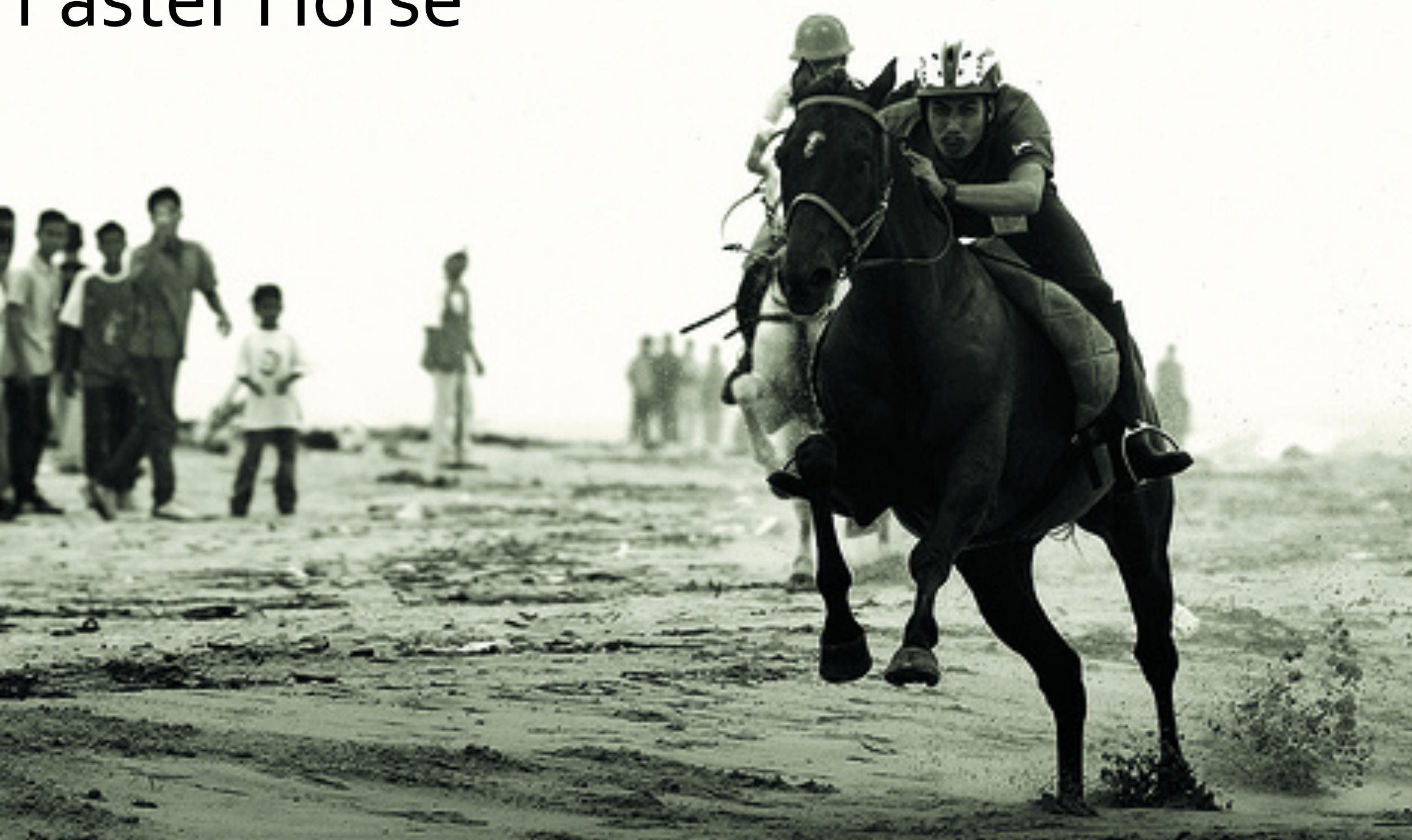


\section{Library Services for Phones}

- Book Study Rooms

- Check hours

- Check borrower record

- Search Catalogue

- Over half wanted to search for articles

- Slightly less than half - read ebooks 


\section{Other Suggestions}

I already find that the library is not user friendly enough, being confined to a tiny box of text would only make matters much much worse. 


\section{Survey Summary}

- In three years up to $80 \%$ with smart phones

- $85 \%$ of students are text messaging

- Environment ripe for some mobile library services

More Selected Survey Results

http://www.ryerson.ca/library/msurvey/ 


\section{Library Mobile Site - Fall 2008}

\section{Ryerson Library}

\section{Mobile Pages}

Hours

Check for Available Laptops

Library News

Contact Us

Research Workshops

Home | 416-979-5055 


\section{Book Study Rooms}

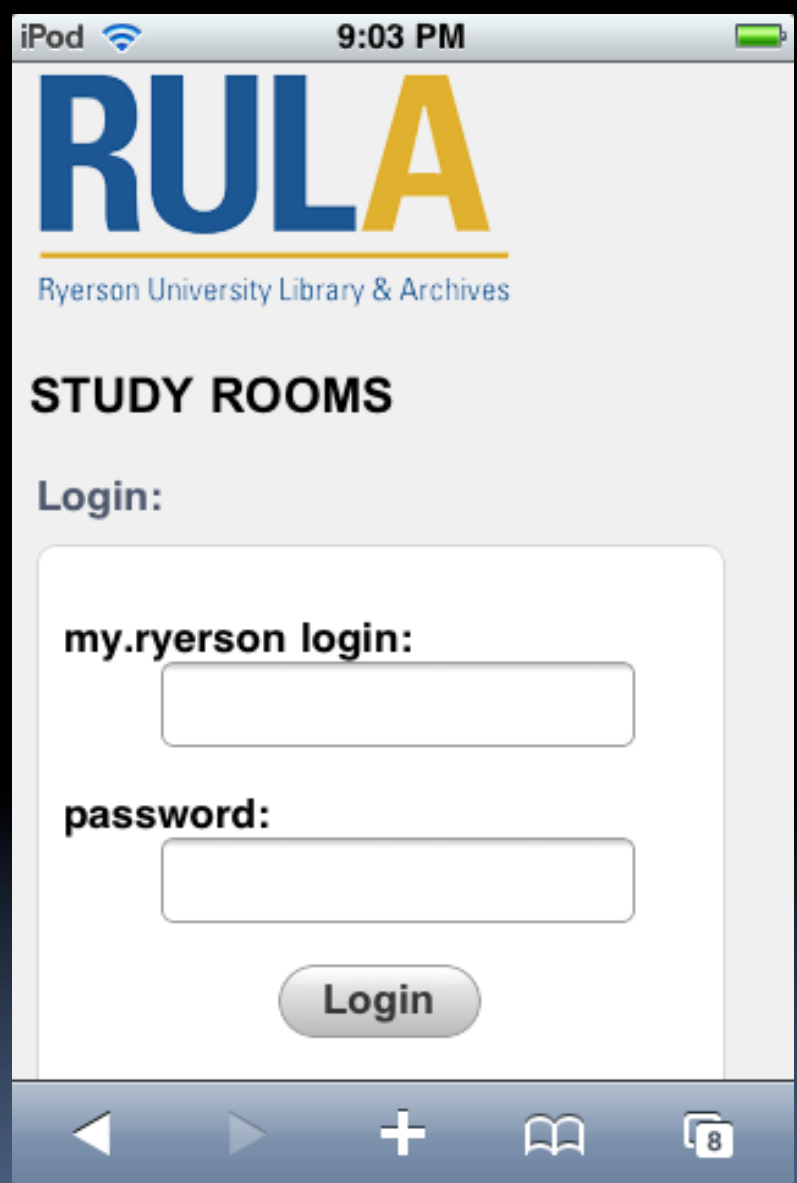

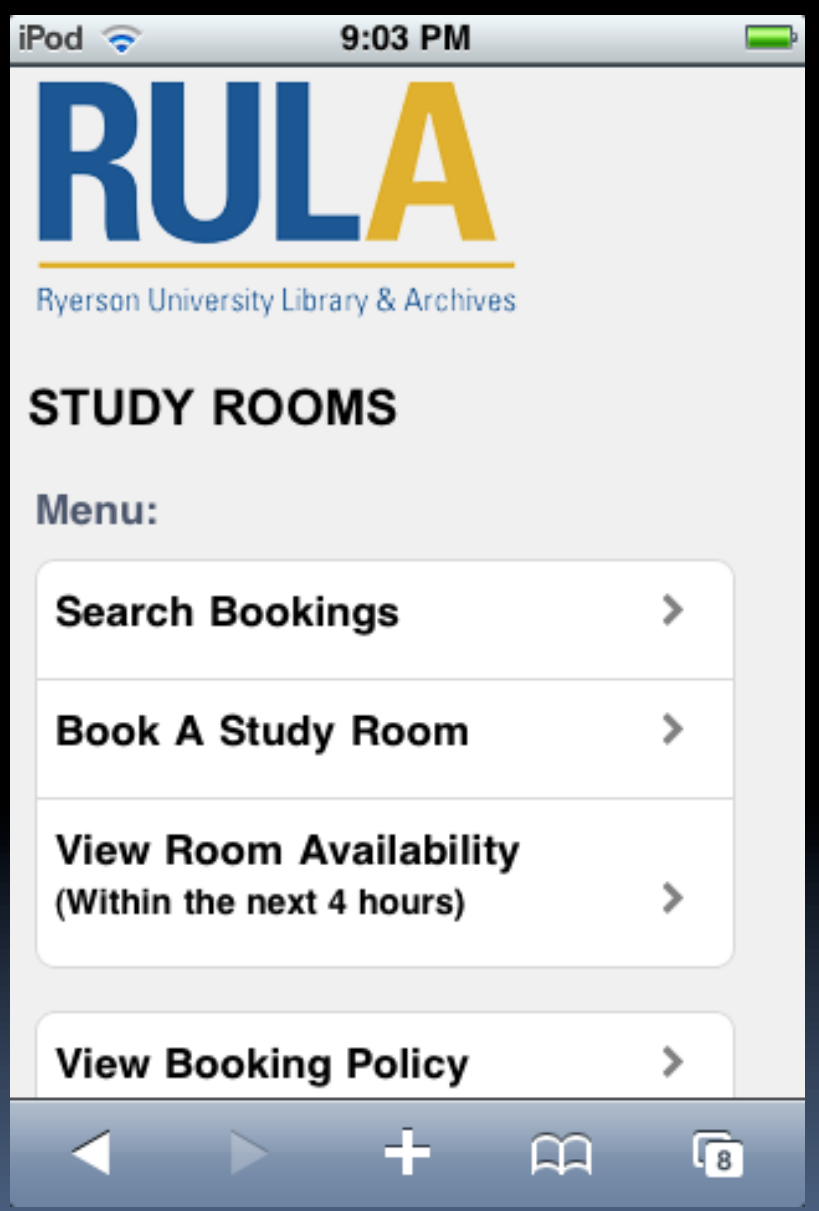




\section{Mobile Catalogue}

- Check Catalogue

- Check Borrower Record 


\section{Build your Own}

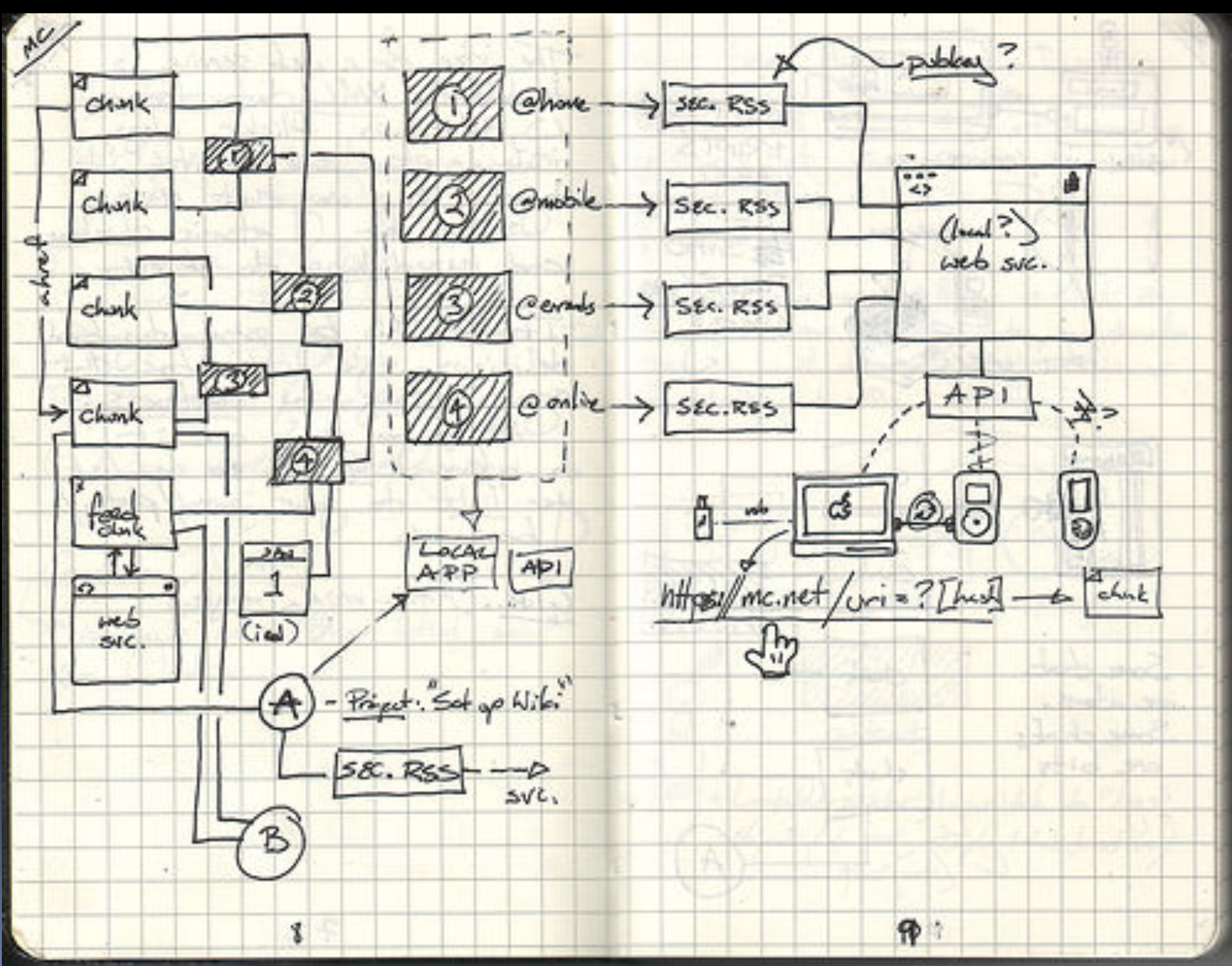

http://www.flickr.com/photos/jazzmasterson/3038597/sizes/m/ 


\section{Innovative's Airpac}

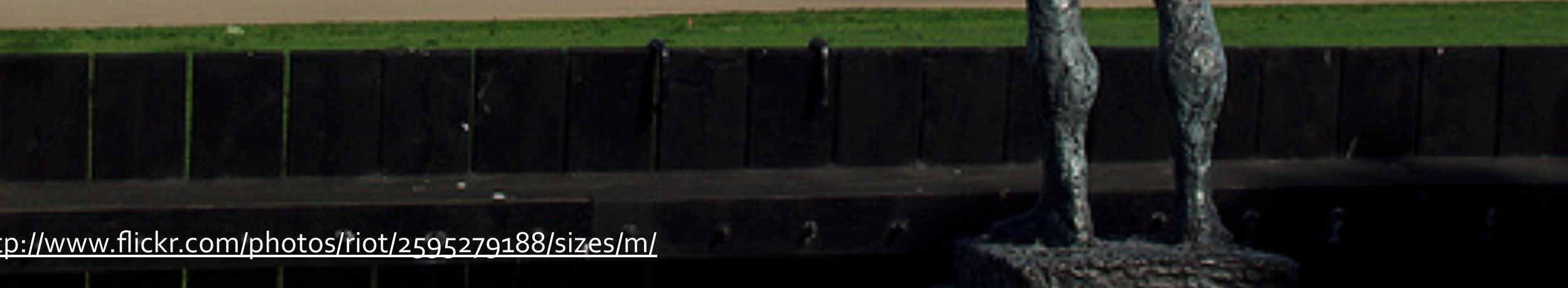




\section{Ryerson Library's Mobile Catalogue}

http://innopac.lib.ryerson.ca/airpac

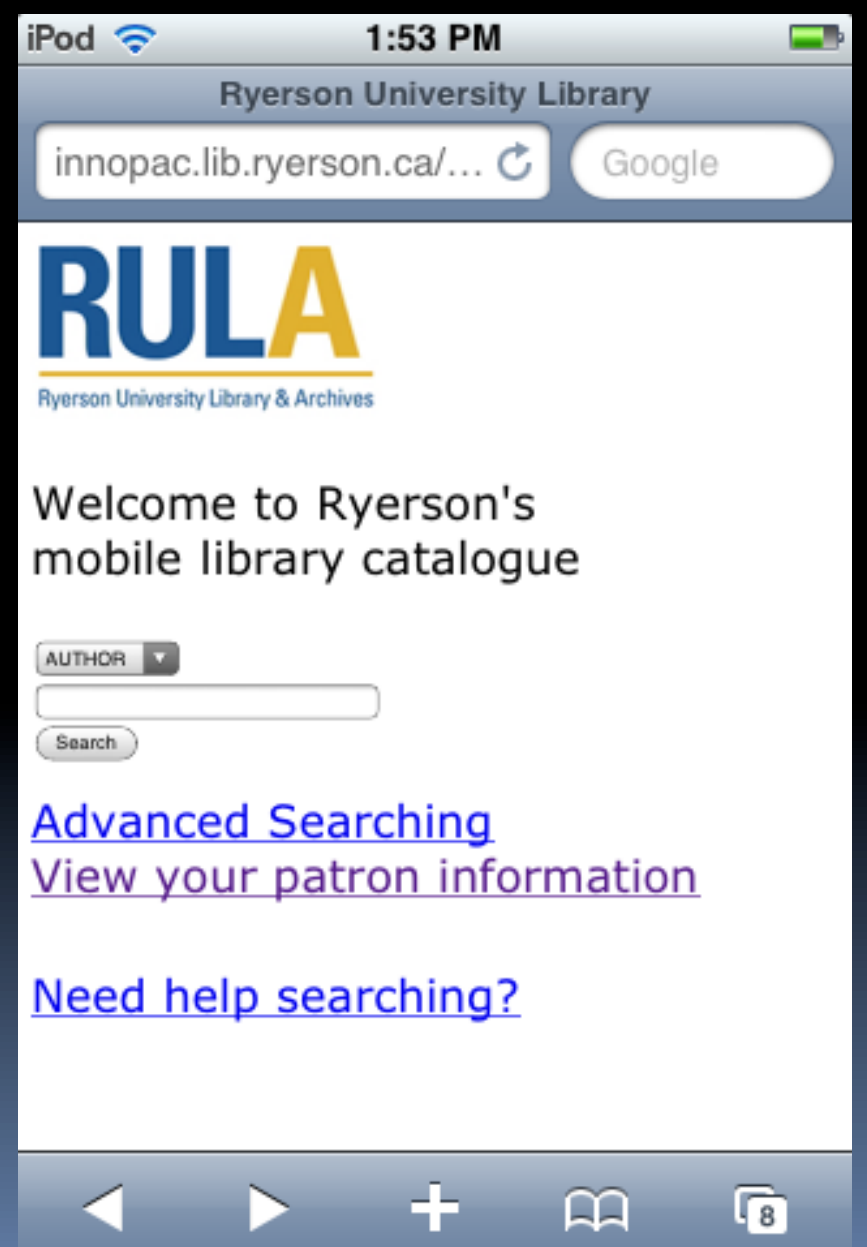

iPod $₹$ 3:57 PM
Ryerson University Library
innopac.lib.ryerson.ca/... C Google

AUTHOR: Boyden Joseph $1-5$ of 5

Boyden, Joseph, 1966-

1. Born with a tooth $/ \ldots-2001$

2. From Mushkegowuk to New... - 2008

3. Three day road / Joseph... - 2008

4. Three day road : a... - 2005

5. Through black spruce /... -2008

Prev Up Next $\underline{\text { Home }}$

$>$ क की $\sqrt{8}$




\section{iPhone AirPAC}

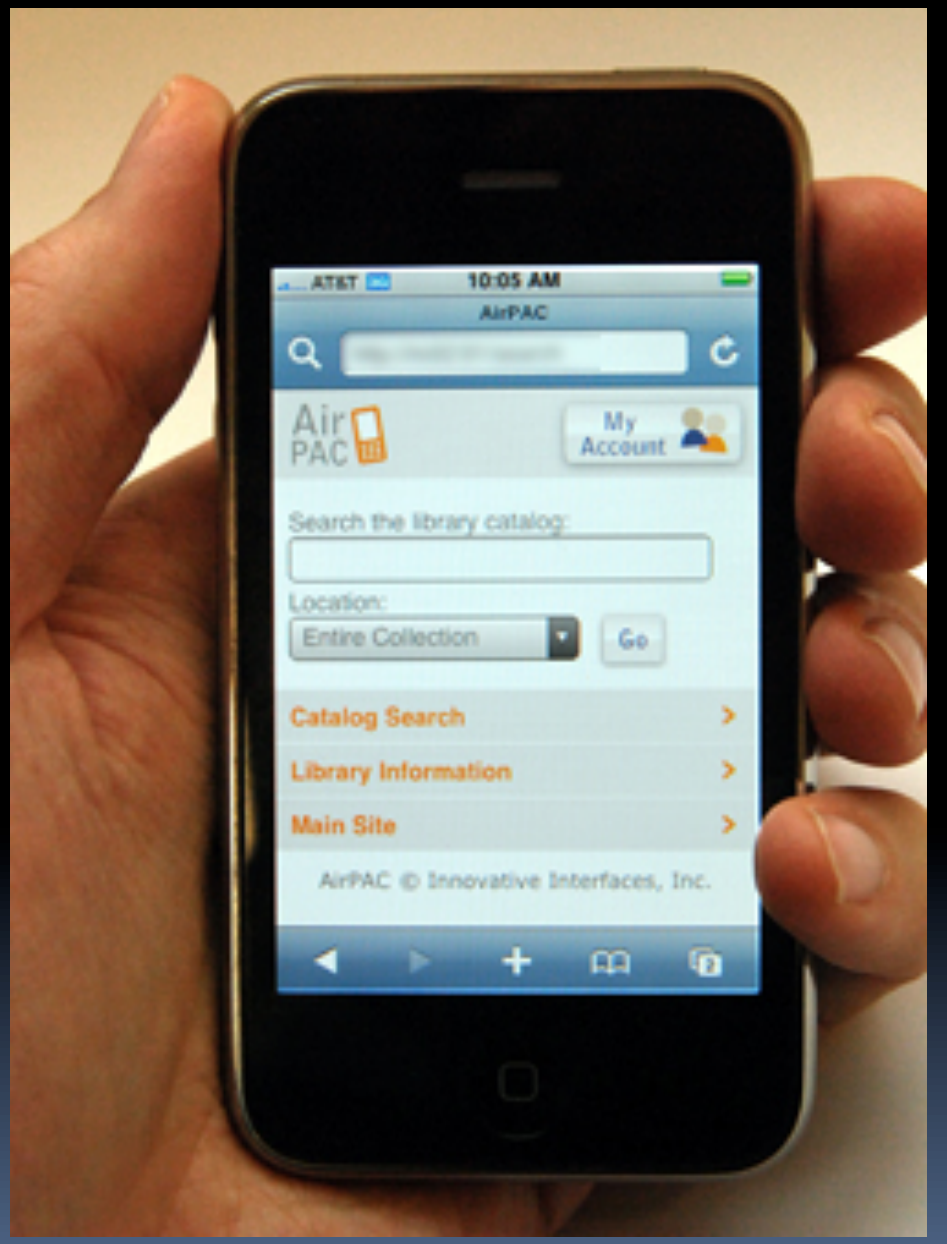

Beta March 2009

Orange County

Library System, FL

http://iii.ocls.info:91/ 


\section{DCPL iPhone Catalogue}
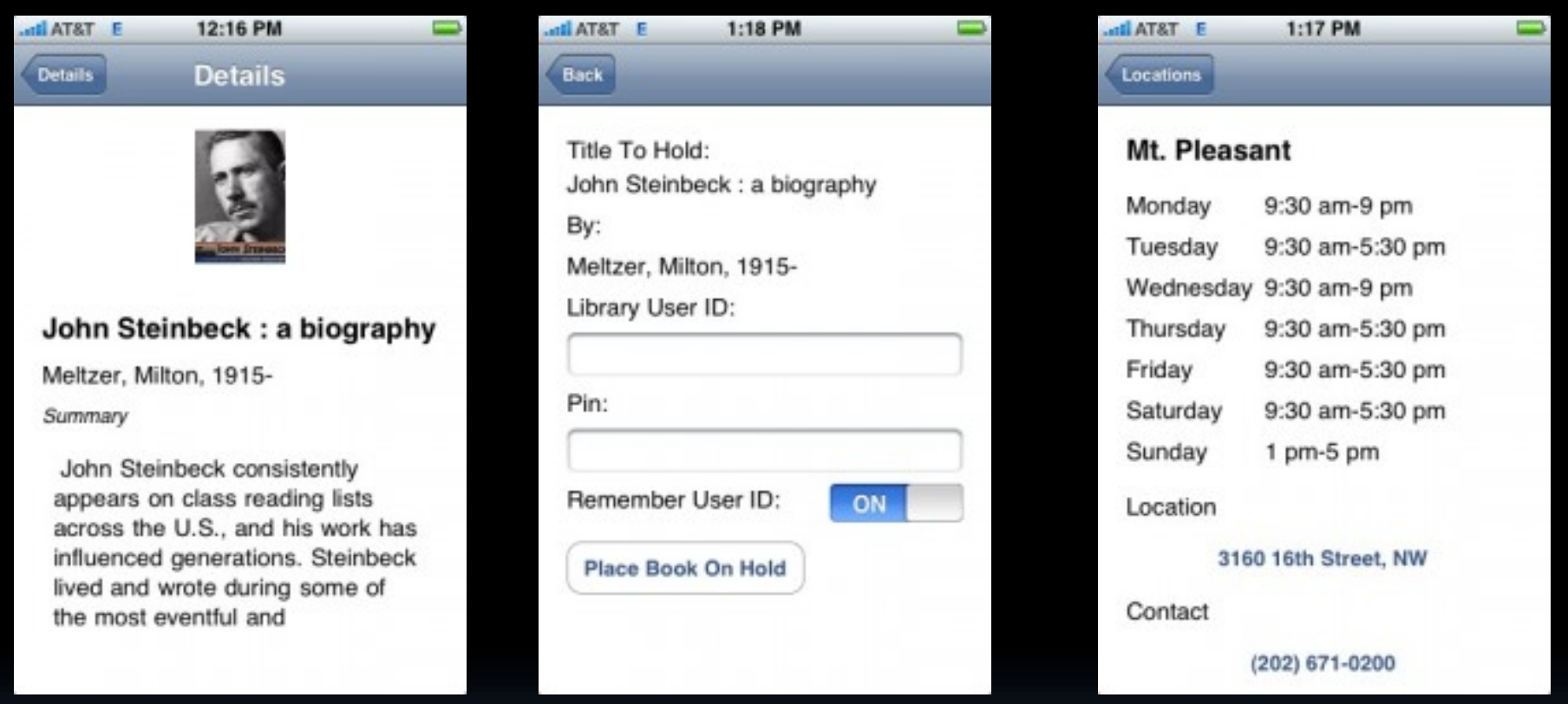

DCPL iPhone app available from iTunes

Software for creating your own version - http://dclibrarylabs.org/projects/iphone/Code 


\section{Current Mobile Website}

www.ryerson.ca/library/mobile/

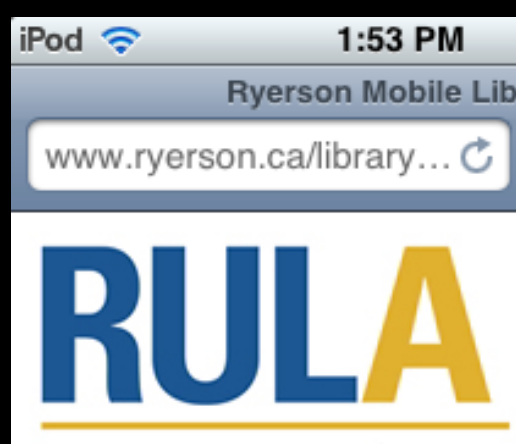

Ryerson University Library \& Archives

\section{Mobile Pages}

Hours

Book a Room

Library Catalogue (Beta)

Check for Available Laptops

Library News

Contact Us

Research Workshops

Home | 416-979-5055

$<>$ की $\sqrt{8}$ 


\section{Text Messaging from Catalogue}

Author Wilson, Emma.

Title Atom Egoyan / Emma Wilson.

Publisher Urbana : University of Illinois Press, c2009.

\begin{tabular}{|l|l|l|}
\hline LOCATION & CALL \# & STATUS \\
\hline$\underline{\text { 9th Floor }}$ & $\underline{\text { PN1998.3.E334 W55 }}$ & AVAILABLE \\
\hline
\end{tabular}

Description xii, 161 p. : ill. ; $21 \mathrm{~cm}$.

Title: Atom Egoyan / Emma Wilson.

Call \#: PN1998.3.E334 W55 2009

Floor: 9 th
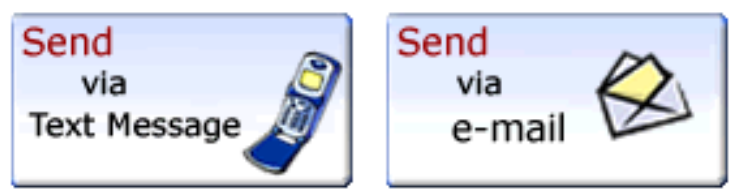

\section{ctors}

əferences (p. 153-158) and index.

[147]-151).

es - - Next of kin -- Family

5 -- The adjuster -- Calendar --

-eafter -- Felicia's journey --

h lies -- Interview with Atom
Add to ORerWorks

(i)

More Information

Send

via e-mail or
text message

Share $f$ On Facebook

\begin{aligned} & \multicolumn{1}{c|}{ Send SMS Message } \\ & Title: Atom Egoyan / Emma Wilson. \\ & Call \#: PN1998.3.E334 W55 2009 \\ & Floor Location: 9th \\ & Select Service \\ & Provider: \\ & Cell Phone \#: \\ & TE: carrier charges may apply \\ & Id Message Go Back. 4161231234 \\ &\end{aligned}




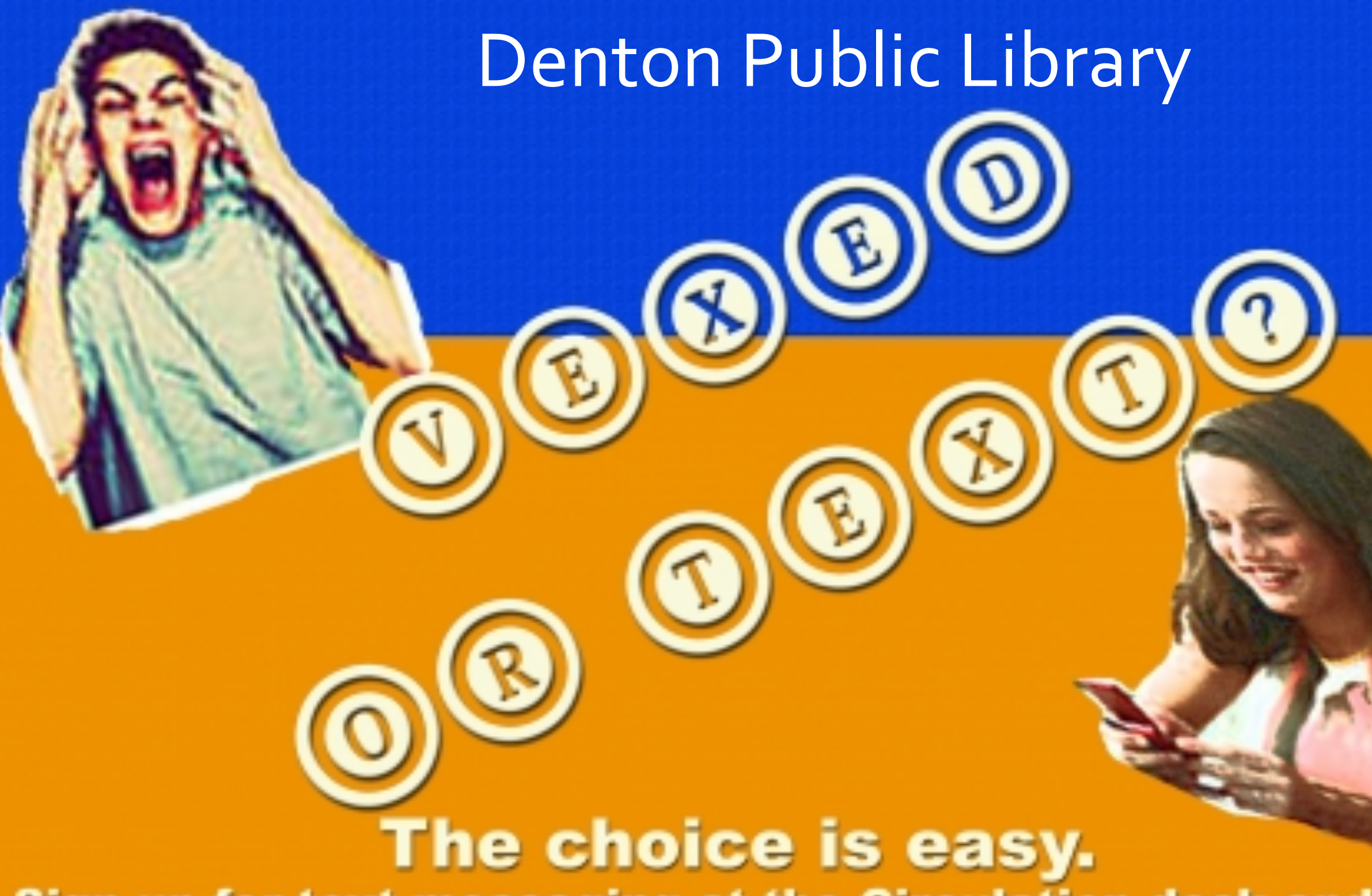

Sign up for text messaging at the Circulation desk and receive text reminders about upcoming due dates and hold pick ups. 


\section{RefWorks Mobile}

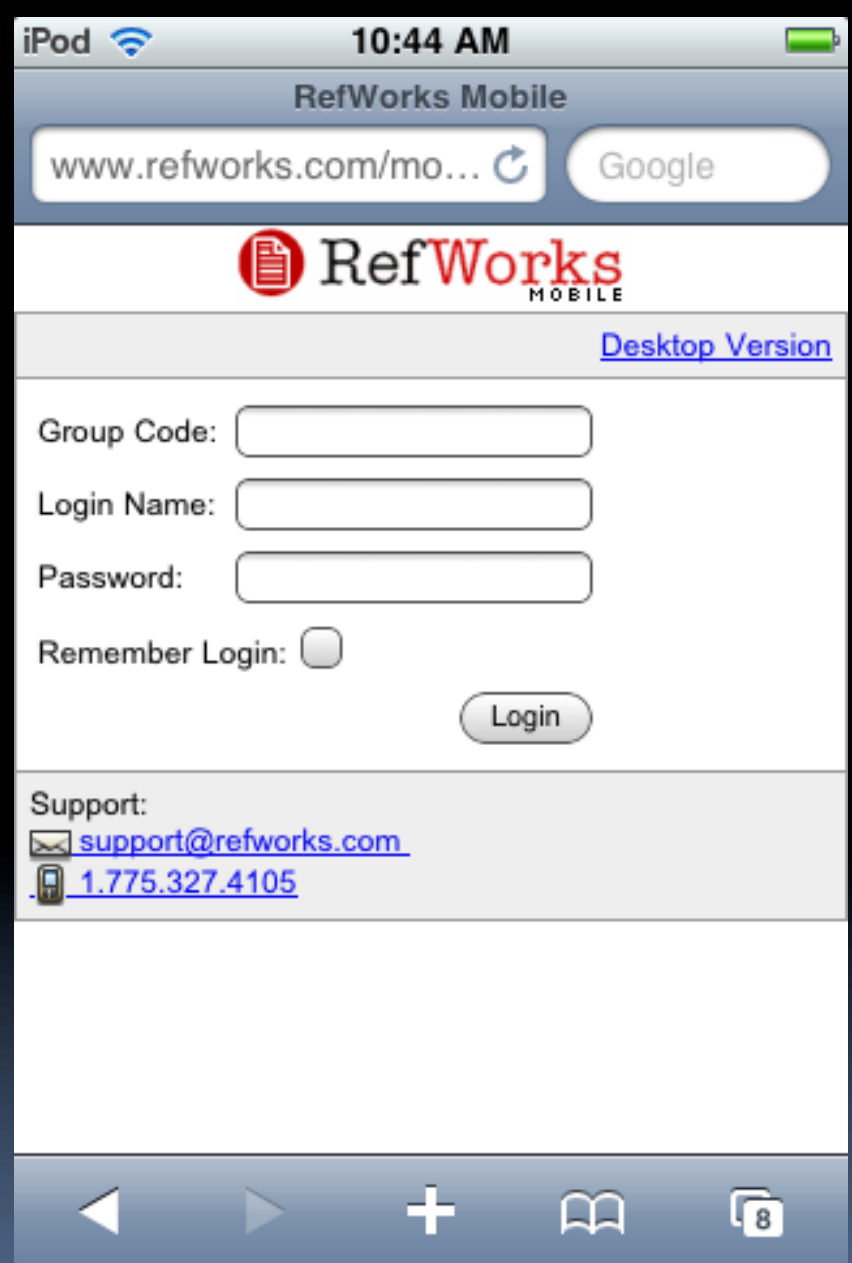

\section{Available with April 2009 upgrade}




\section{Mobile ILL Requests}

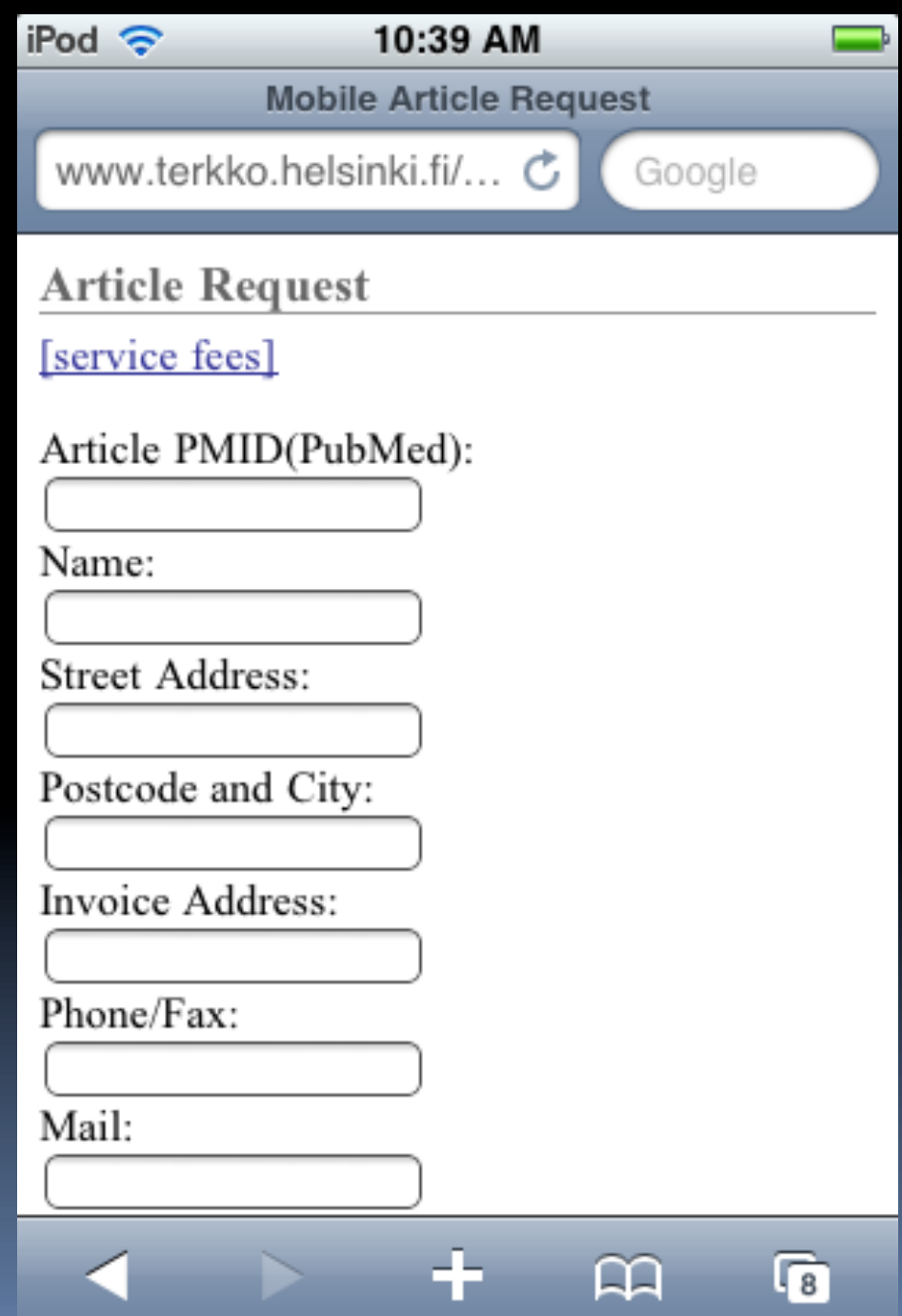

National Library of Health Sciences - Terkko, Finland

\section{Article Request}

[service fees]

Article PMID(PubMed):

Name:

Street Address:

Postcode and City:

Invoice Address:

Phone/Fax:

Mail:

\section{क}




\section{Payment by Phone}

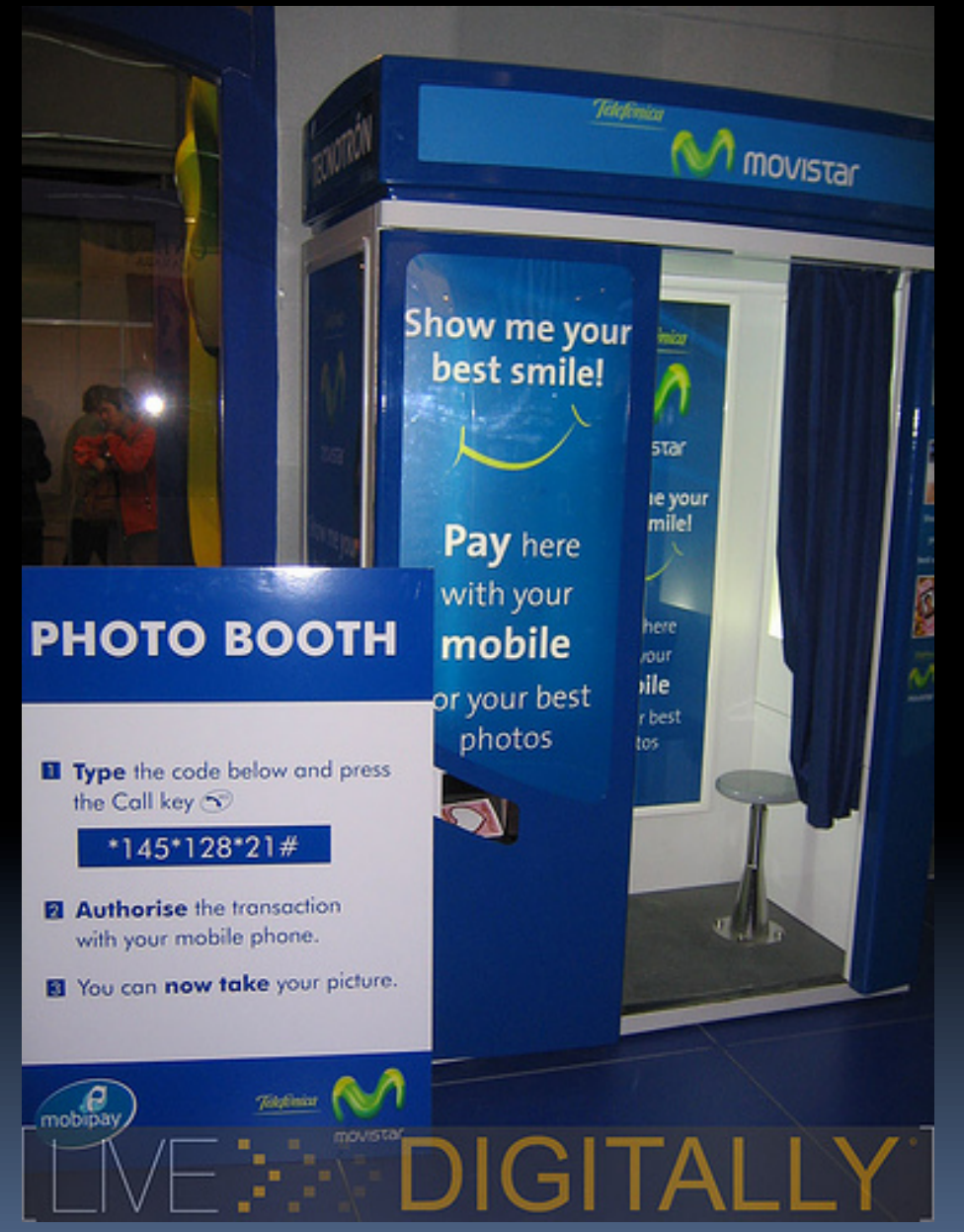

http://www.flickr.com/photos/livedigitally/104695005/sizes/m/

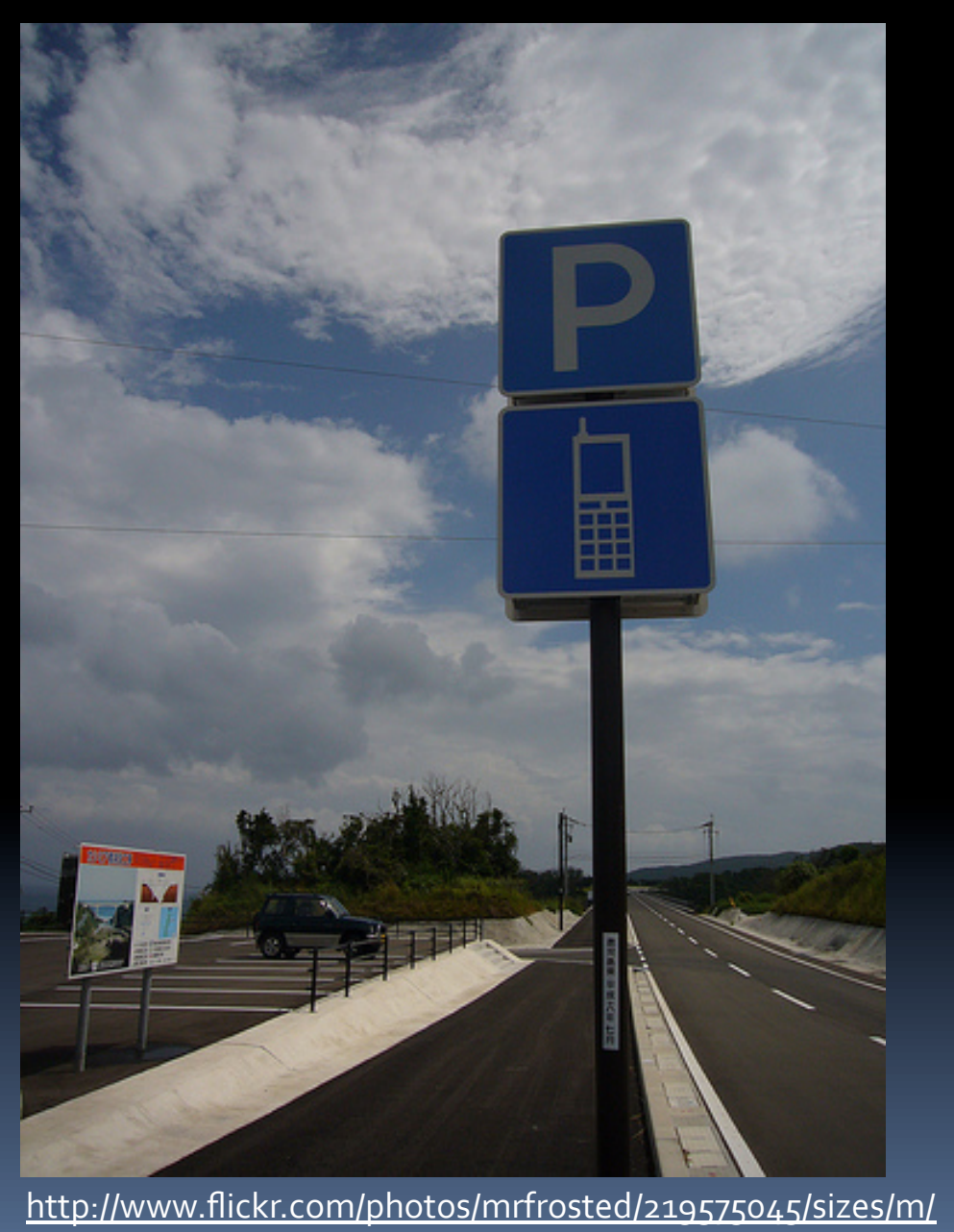




\section{MasterCard Trial}

Just one tap of your phone and you're good to go.

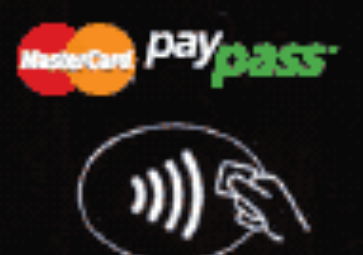

1. Look for this symbol and the PayPass logo at checkout.

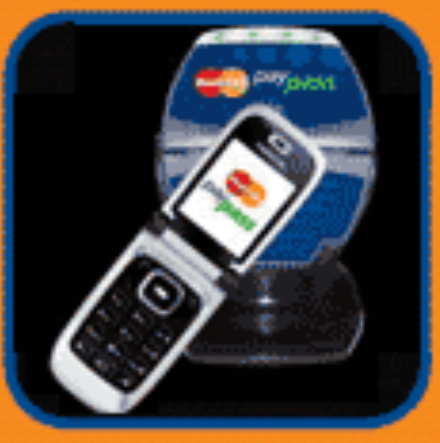

2. Make sure your PayPass application is activated. Then tap your phone on the Paypass reader.

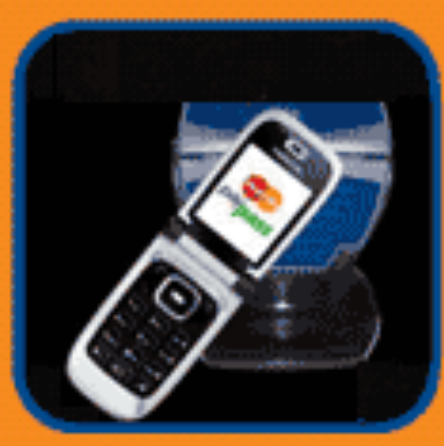

3. When the PayPass Reader lights flash, you're all paid and off you go. 


\section{Barcodes}

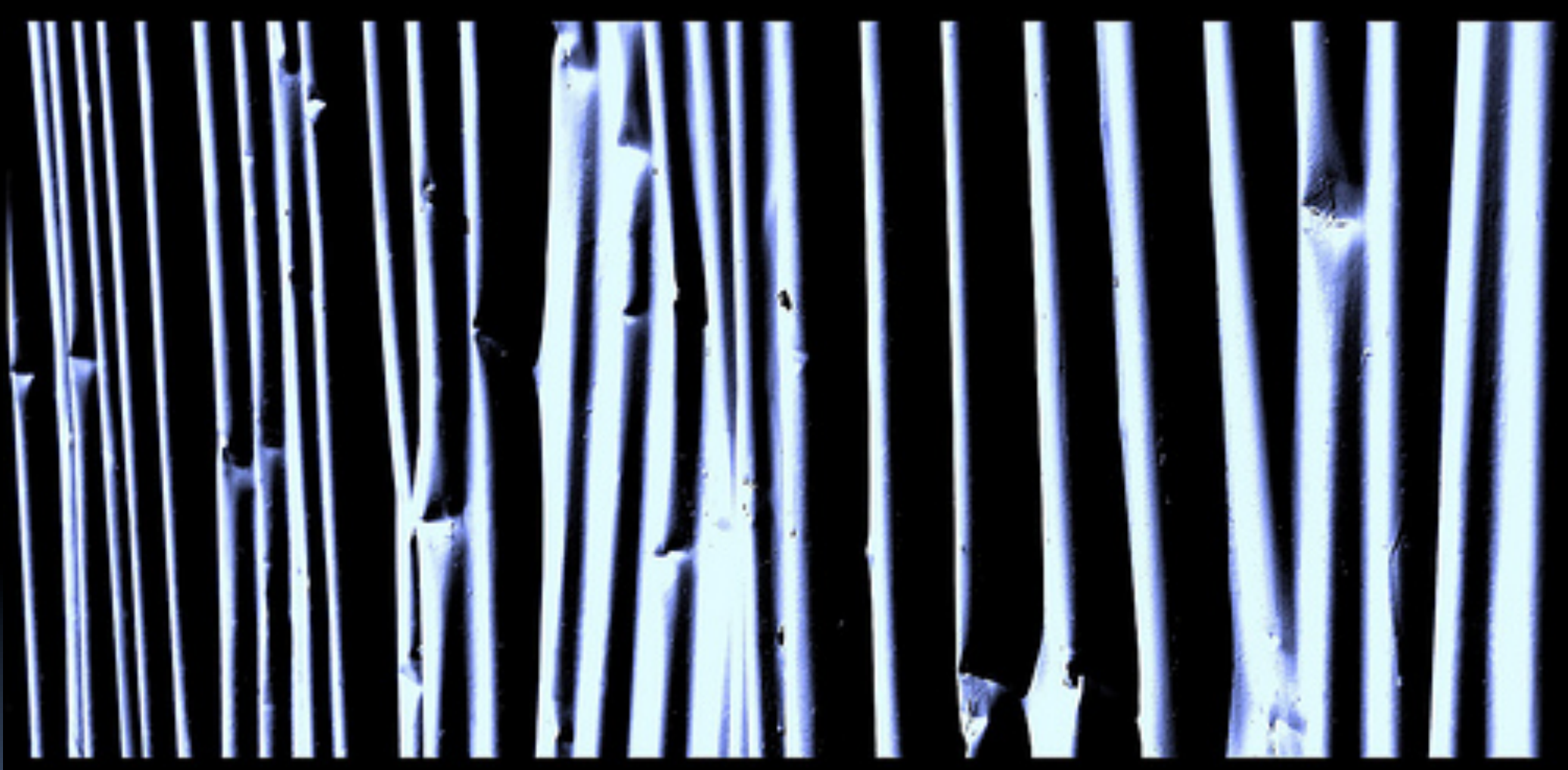




\section{Comparison Shopping}

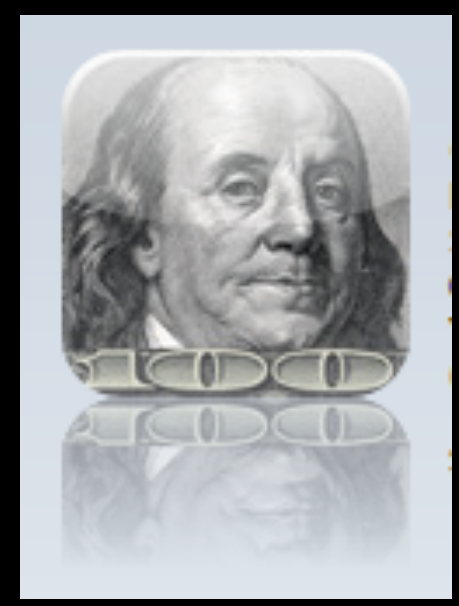

\section{SaveBenjis}

Search by product name, product number, Barcode (UPC,EAN, ISBN), manufacturer, etc

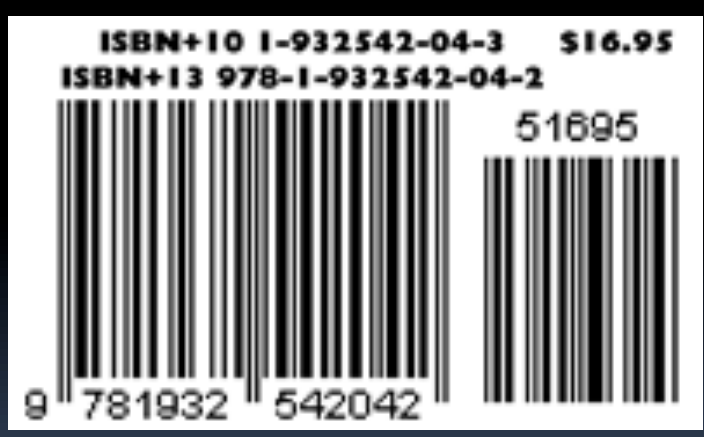




\section{QR Codes}
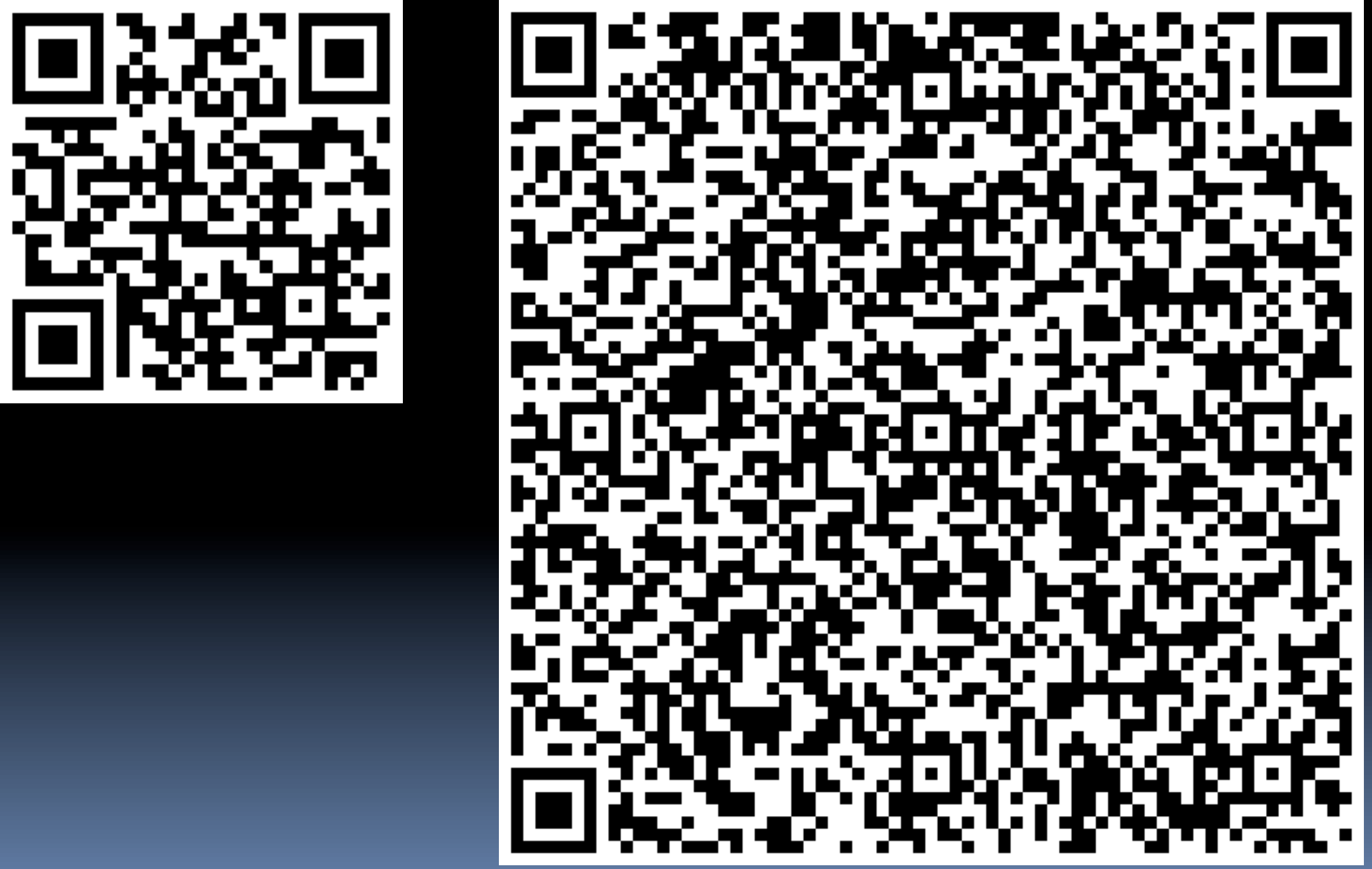


\section{QR Codes in Catalogues}

\section{Library Services}

UNIVERSITY OF

UoB home: $a-z$ | contact

search

G०

About

Catalogue

Subjects

Online Resources

Your use of the Library

Help

result 1 of 1 for search "tradescant" in anywhere

\section{Save}

The John Tradescants : gardeners to the rose and lily queen

Leith-Ross, Prudence.

Publisher: Owen,

Publication date: 1984.

ISBN: 0720606128

1 copy on the shelves at Library \& Learning Centre (Univ of Bath).

Copy details

Library \& Learning Centre (Univ of Bath)

> Place Hold

> Permalink for this result

> Find more by this author

> Find more on these topics

> Order online from BLACKWELL

Shelf mark

635.09:920TRA
No. of copies Loan type

128 day loan

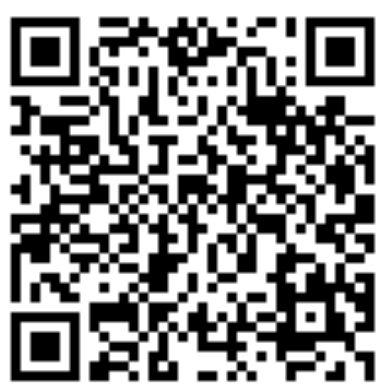

What's this?
Location

Level 4 (see

floorplan) 
